\title{
Zooarchaeological and Genetic Evidence for the Origins of Domestic Cattle in Ancient China
}

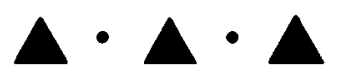

Lu Peng, Katherine Brunson, Yuan Jing, and Li Zhipeng

\begin{abstract}
This article reviews current evidence for the origins of domestic cattle in China. We describe two possible scenarios: 1) domestic cattle were domesticated indigenously in East Asia from the wild aurochs (Bos primigenius), and 2) domestic cattle were domesticated elsewhere and then introduced to China. We conclude that the current zooarchaeological and genetic evidence does not support indigenous domestication within China, although it is possible that people experimented with managing wild aurochs in ways that did not lead to complete domestication. Most evidence indicates that domestic taurine cattle (Bos taurus) were introduced to China during the third millennium B.C., and were related to cattle populations first domesticated in the Near East. Zebu cattle (Bos indicus) entered China sometime between 2000 and 200 в.C., but much less is known about this species. The role of cattle as ritual and wealth animals seems to have been critical to their initial introduction. KEYwords: cattle, domestication, management, zooarchaeology, Neolithic and Bronze Age China.
\end{abstract}

\section{INTRODUCTION}

IN THIS ARTICLE, WE SUMMARIZE THE CURRENT STATE of genetic and zooarchaeological research on cattle domestication in China. Despite the importance of cattle in ancient and modern Chinese societies, there is no English-language synthesis of the zooarchaeological evidence for the origins of Chinese cattle. Our aim is to present the most current list of sites where domestic cattle bones have been securely identified in order to evaluate recent claims for indigenous domestication of Chinese cattle from wild aurochs. We argue that there is no definitive evidence that domestic cattle were present in China prior to about 3600 B.C. Instead, cattle were likely introduced to China during the Late Neolithic period (fourth to third millennium B.C.), possibly through trade routes connecting China and Central Asia. Finally, we discuss some of the ways that ancient people initially exploited cattle for subsistence, labor, raw materials, and rituals. The archaeological evidence for how cattle were used in the Late

Lu Peng is an associate professor of archaeology at the Institute of Archaeology, Chinese Academy of Social Sciences. Katherine Brunson is a postdoctoral fellow at the Joukowsky Institute for Archaeology and the Ancient World at Brown University. Yuan Jing is a professor of archaeology at the Institute of Archaeology, Chinese Academy of Social Sciences. Li Zhipeng is an associate professor of archaeology at the Institute of Archaeology, Chinese Academy of Social Sciences. 
Neolithic offers insight into how they became one of the most important ritual animals in Bronze Age China.

\section{BACKGROUND: ANIMAL DOMESTICATION IN ANCIENT CHINA AND OTHER CHINESE BOVINES}

The past few decades of zooarchaeological research have produced important data on the processes of animal domestication in China (Yuan 2008, 2015). Although some animals were domesticated from native Chinese species, many other domesticates were introduced to China from neighboring regions. For example, pigs were domesticated independently in China during the Early Neolithic c. 6600-6000 B.C. (Cucchi et al. 2011; Larson et al. 2005; Larson et al. 2010; Luo 2012; Yuan 2010; Yuan and Flad 2002). Other domesticates do not appear in China until the Late Neolithic and early Bronze Age, when agriculture was already well established. For example, sheep arrived in China by c. 3600-2000 B.C. (Flad et al. 2007; Yuan et al. 2007) and horses by c. 1370 B.C. (Flad et al. 2007; Linduff 2003; Yuan and Flad 2006; Yuan et al. 2007). These animals were introduced to China during periods of increasing long-distance trade and exchange both within China and across Eurasia (Anthony 2007; Chang 1986 :234-294; Frachetti 2008; Jaang 2015; Kohl 2007; Sherratt 2006).

There is a good deal of debate about the origins of domestic Chinese bovines. East Asia was once home to several native wild bovines including water buffalo (Bubalus mephistopheles), aurochs (Bos primigenius), bison (Bison exiguus), gaur (Bos/Bibos gaurus), and yak (Bos/Poephagus mutus) (Zhang 2001; Zhongguo Kexue 1959; Zhongguo Kexue 1979). With the exception of the gaur and wild yak, these species are now extinct. Wild water buffalo bones have been found at many Neolithic and Bronze Age sites, including sites in the Lower Yangzi River Basin dating to c. 5000-3000 B.c. where water buffalo scapulae were used to make agricultural tools (Liu et al. 2004; Liu et al. 2006; Xie 2014). The earliest archaeological evidence for domestic water buffalo in China comes from textual and artistic depictions from Southwest China dating to after the first century A.D. (Liu et al. 2006). Modern DNA research indicates that the origin of domestic swamp water buffalo (Bubalus bubalis) may be traced to this region, but it is also possible that water buffalo were first domesticated in parts of Southeast Asia and then introduced to Southwest China (Yue et al. 2013). Ancient DNA analysis of water buffalo remains from Bronze Age sites dating to c. 2000 B.C. in the Yellow River Valley indicates that these animals were all wild water buffalo (Bubalus mephistopheles) that did not contribute genetically to modern Chinese domestic water buffalo populations (Yang et al. 2008). It remains unclear when wild water buffalo in China went extinct and when they were replaced by domestic water buffalo populations.

Domestic yaks (Bos/Poephagus grunniens) may have been domesticated from wild yaks somewhere on the Qinghai-Tibetan Plateau (Flad et al. 2007). Yak milk, meat, and dung are important to life at high altitudes in this region, but the process of domestication is based solely on modern geographic distributions and there is still no clear zooarchaeological evidence for the process of yak domestication (Flad et al. 2007; Rhode et al. 2007). Modern genetic evidence indicates that yaks were domesticated sometime during the Holocene, perhaps even before 7000 years ago (Guo et al. 2006; Qiu et al. 2015). Ancient DNA and zooarchaeological evidence are still needed to confirm these claims. 
To date, there are no zooarchaeological or ancient DNA studies of bovines in the gaur lineage. Modern genetic research indicates that the gayal (Bos frontalis) was domesticated from the gaur and subsequently underwent significant hybridization with domestic cattle populations in Southwest China (Gou et al. 2010; Verkaar et al. 2004). It is still unclear whether gayal were first domesticated in Southwest China or elsewhere in Indochina.

\section{EVIDENCE FOR INDIGENOUS CATTLE DOMESTICATION IN CHINA}

The origins of domestic Chinese water buffalo, yaks, and gayal remain elusive due to the paucity of zooarchaeological and ancient DNA data. Although we have more information for domestic cattle, the complex relationships between domestic cattle and ancient wild Chinese bovines are also unclear.

Zooarchaeologists and geneticists are currently in general agreement that all cattle worldwide were domesticated from the now extinct wild aurochs (Bos primigenius) in two domestication episodes: one in the Near East by c. 8000 B.c. that gave rise to taurine cattle (Bos taurus) (Bradley and Magee 2006; Helmer et al. 2005; Hongo et al. 2009 ) and another in South Asia by roughly 6000 B.C. that gave rise to zebu cattle (Bos indicus) (Bradley and Magee 2006; Grigson 1985; Meadow 1996; Meadow and Patel 2003). Although the current genetic evidence indicates that there were two independent centers of cattle domestication, Larson and Burger $(2013: 202)$ note that the branching patterns seen in mtDNA and Y-chromosomal DNA phylogenetic trees that are used to support the two-center model can also be explained by phenomena such as population structure or genetic drift. Therefore, it is still possible that there was only a single center of cattle domestication in the Near East. Further genetic evidence is needed before we can rule out the possibility that zebu cattle reflect later admixture with South Asian wild auroch populations.

With the exception of Zhang and colleagues (2013), discussions on the origins of domestic cattle have not examined specifically the possibility that people managed or even domesticated wild cattle in East Asia. Aurochs were naturally distributed across Eurasia and into China during the Holocene (van Vuure 2005), but previous zooarchaeological and ancient DNA research indicates that Chinese aurochs were never domesticated, and that domestic cattle were introduced to China from West Asia (Cai et al. 2014; Flad et al. 2007; Yuan et al. 2007). New evidence, including recent genetic analysis of an early Holocene specimen with stereoscopic tooth wear and unique mtDNA signature, offers an intriguing picture of complex animal management strategies and raises the question of whether there was a third, as yet undiscovered, domestication event in China (Zhang et al. 2013). We discuss this evidence in detail below.

Cattle have been identified at many Chinese archaeological sites (Table 1; Fig. 1). Specimens with earlier dates often come from unsecure contexts or prove to be wild bovines after re-evaluation. For example, for many years scholars believed that domestic cattle were present at the site of Cishan in Hebei Province (c. 6500-5000 B.c.) (Chen 2005 : 57; Wu and Huang 1997; Zhou 1981). However, re-evaluation demonstrated that the Cishan bones are larger than domestic cattle bones and are more similar in size to Pleistocene-era wild Bison sp. and Bos from North China (Anhui 1992; Lu 2010b; Zhongguo Kexue 1959: 70). Similarly, cattle remains were identified at the site of Jiahu in Henan Province (c. 7000-5500 в.с.) (Henan 1999: 785-805), 
but reanalysis indicates that these specimens are morphologically similar to water buffalo (Bubalus mephistopheles) (Luo et al. 2015). Bones identified as Bos have also been found at the Neolithic sites of Baiyinchanghan in Inner Mongoila (Tang et al. 2004), Xiaojingshan in Shandong Province (Kong 1996), and Peiligang in Henan Province (Kaifeng et al. 1979; Zhongguo Shehui 1984); these also likely represent wild hunted animals. The current evidence indicates that there are no archaeological sites with definitive zooarchaeological evidence for domestic cattle dating to before c. 3600 B.c. Nevertheless, wild cattle were occasionally hunted at earlier Neolithic sites.

Recently, Zhang and colleagues (2013) identified a Bos mandible dating to c. $10,600 \mathrm{cal}$ B.P. Found near Harbin in Northeast China, it may provide new evidence for early experimentation with cattle management. Zhang and colleagues found that the lower P4 and M1 teeth on the mandible were heavily worn (Fig. 2a). They argue that such a wear pattern may have been caused by bar-biting or repeated chewing of hard objects, which they interpret as evidence for human management of this animal. Comparisons between mtDNA from the mandible and mitogenome sequences from modern bovine species indicate that the mandible belongs to a new and unique Bos haplogroup, haplogroup C. Because millet cultivation was taking place in northern China around roughly the same time (Yang et al. 2012), Zhang and colleagues (2013) propose that people may have experimented with managing animals.

We have argued elsewhere that such claims are premature (Lu et al. 2014). This new find seems to upend the current consensus about cattle domestication, but it is a unique sample and the evidence for intentional human management is weak. Zhang and colleagues (2013) do not include information about the stratigraphic, taphonomic, and depositional factors that influenced the context of the specimen. It is unclear whether there was even human habitation at the site where the mandible was found. Additionally, they present a single line of evidence-symmetrical wear on the lower P4 and M1 teeth - to claim that people were managing this individual bovine. Archaeological studies of bit-wear in horses have shown that wear is usually asymmetrical and manifested on the lower P2 teeth (Anthony 2007: 194, 207-213; Olsen 2006). We are unaware of similar studies for cattle tooth wear.

During our own observations of modern skeletal comparative collections of ungulates from China, we found that extreme wear on the P4 and M1 can be found in both wild and domestic ungulates of older ages (Fig. 2b-e). Such tooth wear is likely caused by long-term grinding of the mandibular teeth against the maxillary teeth. The mandibular M1 is the first adult tooth to erupt, making it subject to the most extended wear during an animal's life (Grigson 1982; Hillson 2005 :232). The heavy wear that Zhang and colleagues (2013) observed on the lower P4 and M1 on the mandible from Northeast China could be due to the age of the animal and extended grinding against the maxillary teeth. Without the associated maxilla or associated archaeological materials, we cannot rule out the possibility that the wear pattern on the $10,600 \mathrm{cal}$ B.P. mandible is natural and therefore not yet definitive evidence of cattle management. The mtDNA does not match any known modern Bos haplogroups because the mandible is from a now-extinct East Asian form of Bos primigenius that did not contribute genetically to later domestic cattle. There is currently insufficient evidence to suggest that there was management of this now extinct species.

Although we do not believe that the cattle mandible in question represents a managed individual, the 2013 study by Zhang and colleagues still raises two significant 


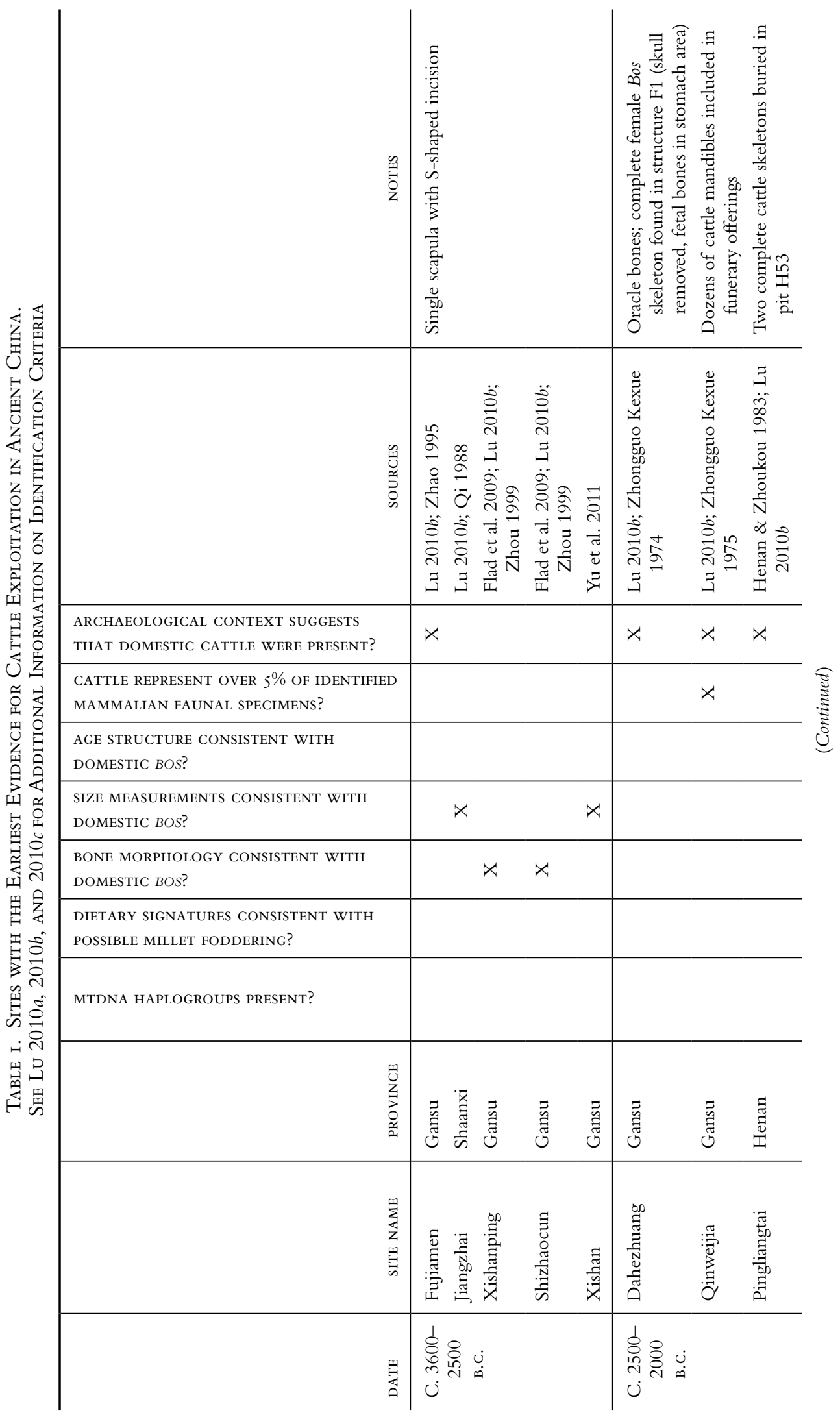




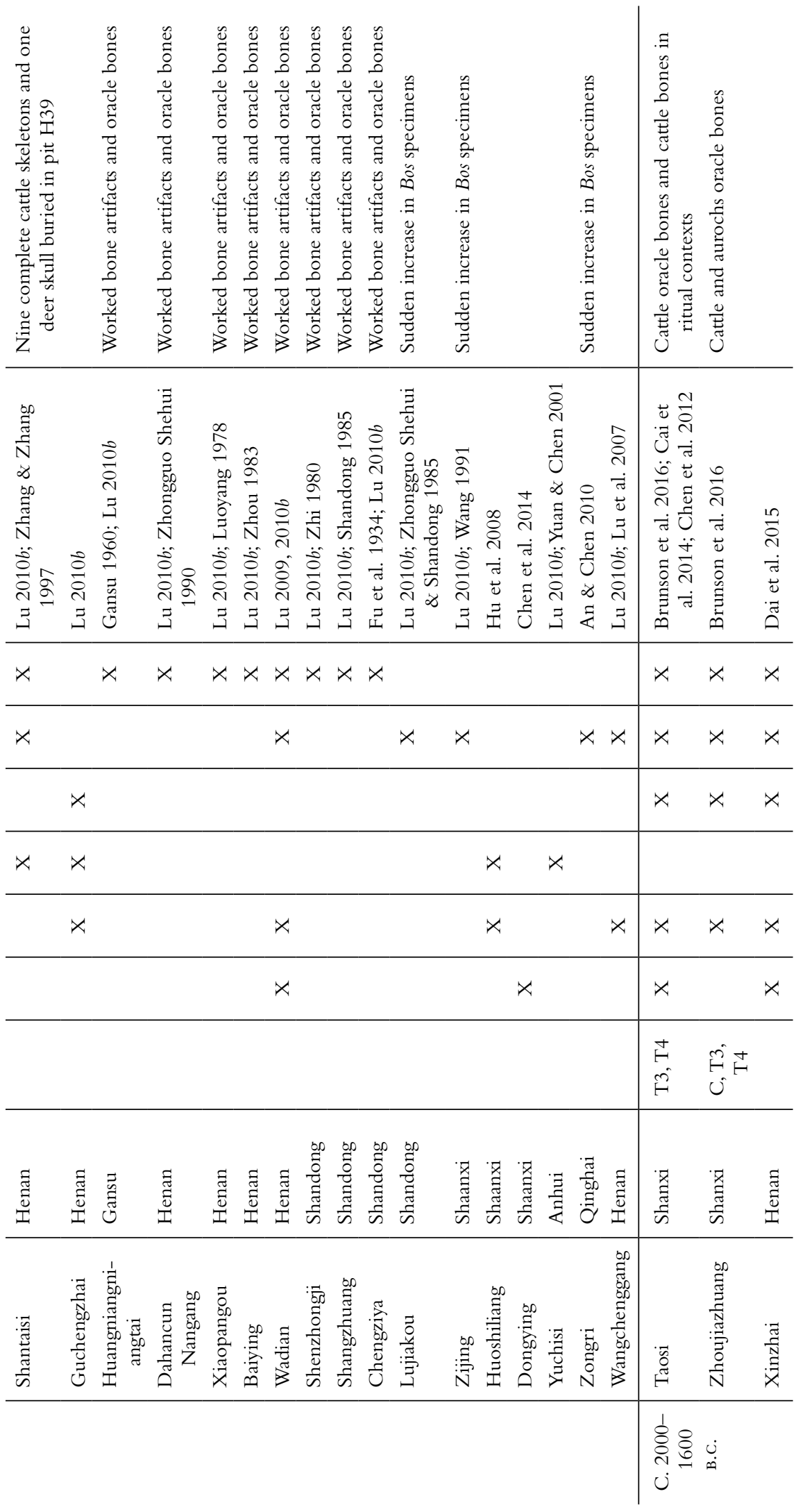




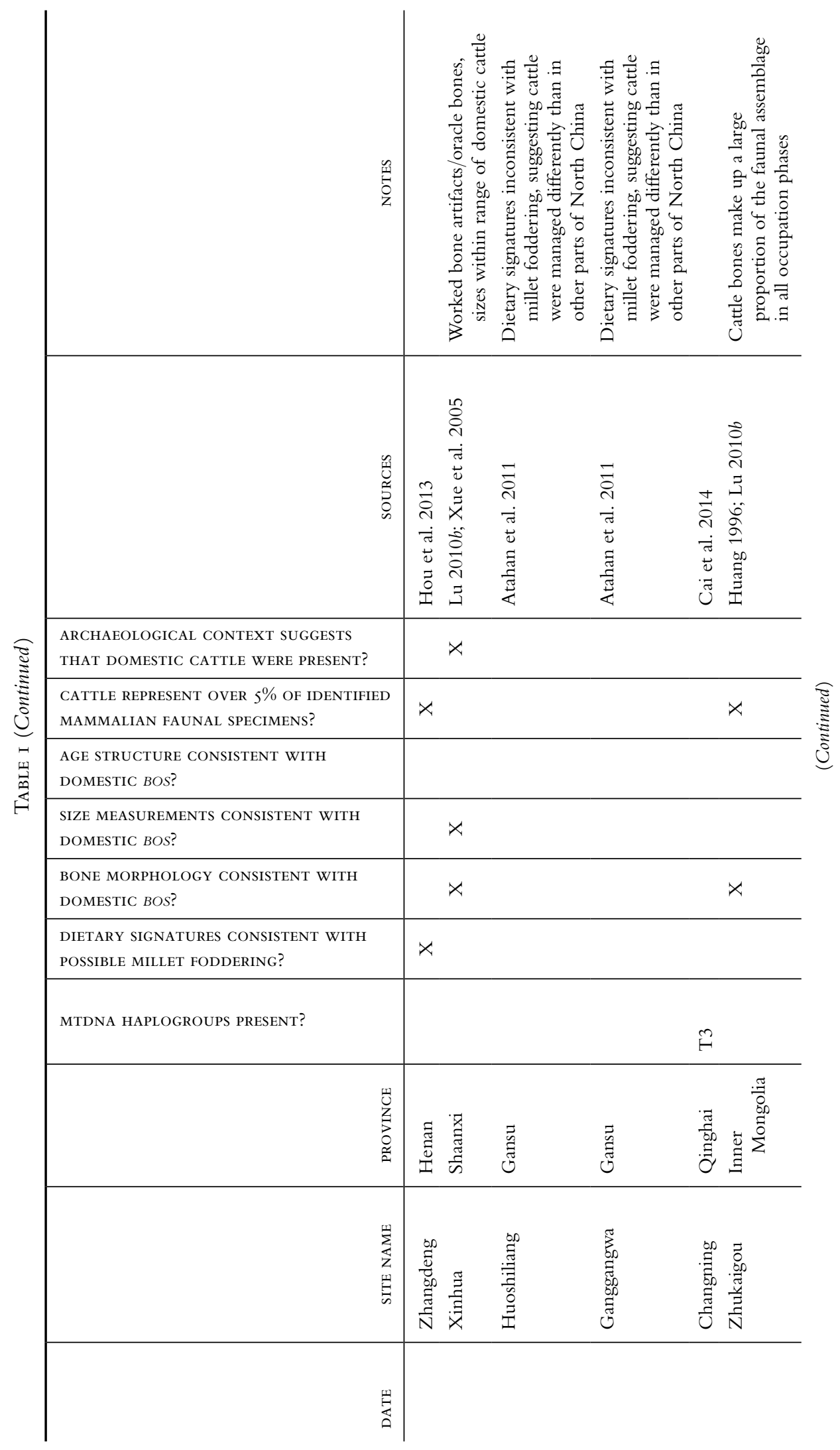




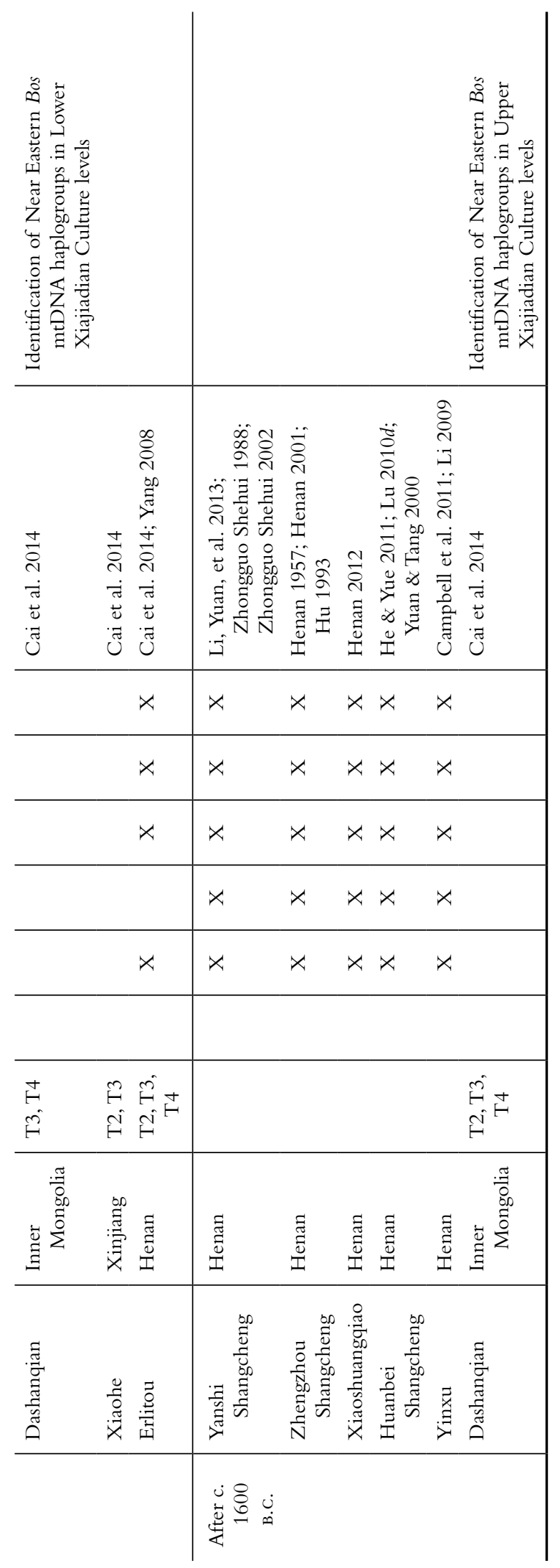



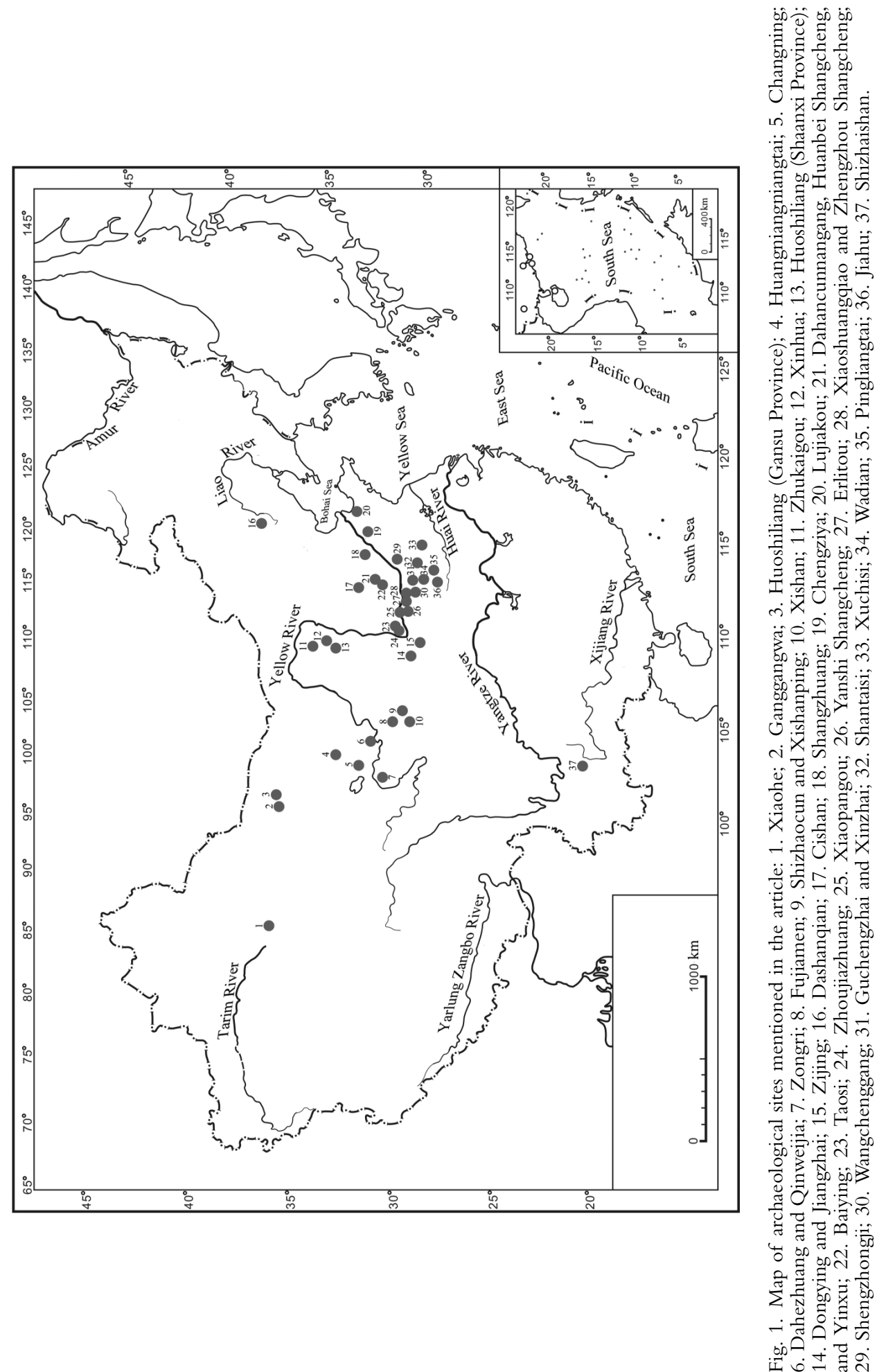

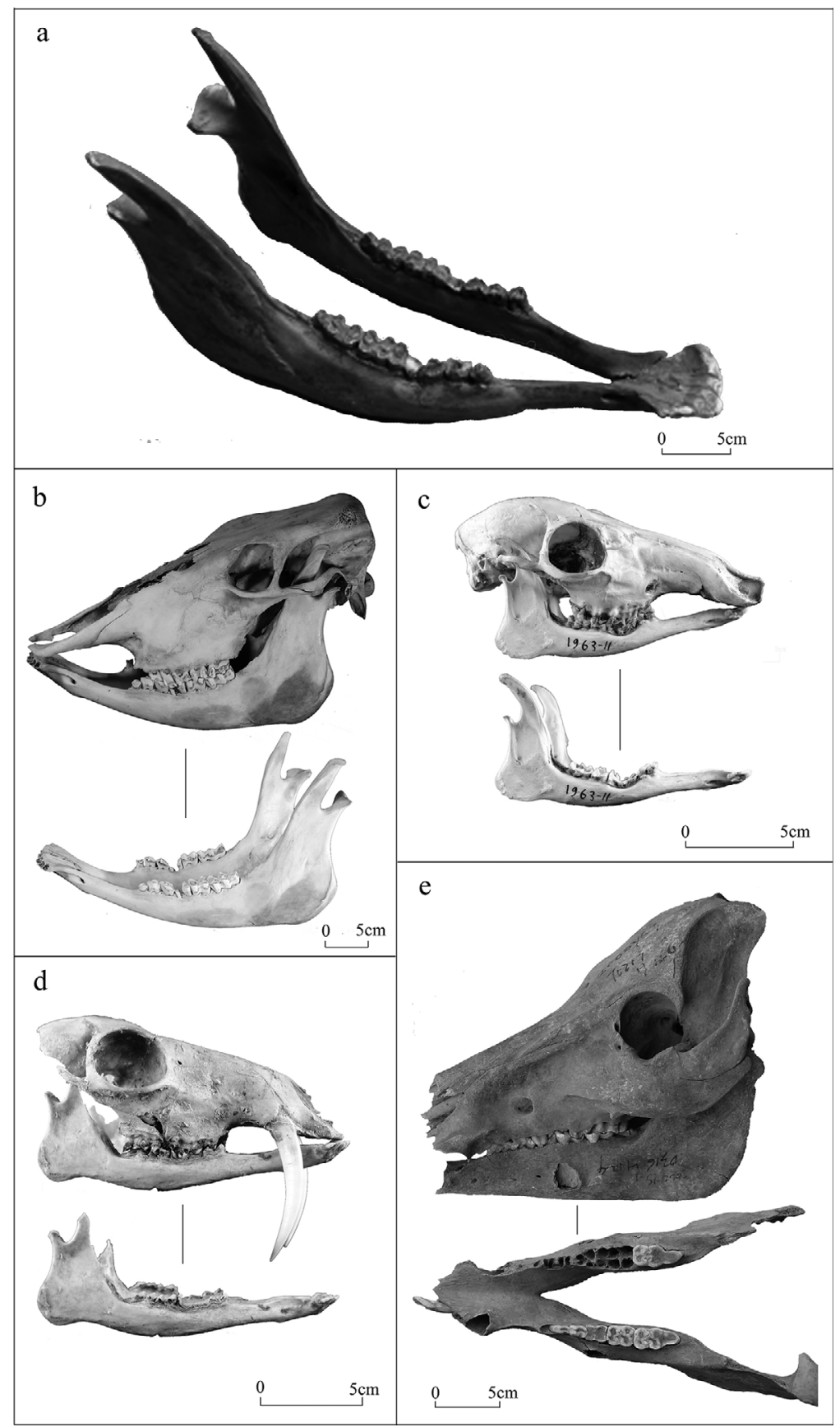

Fig. 2. Severe wear on the mandibular P4 and M1 of old age ungulates: a) Bos mandible from Northwest China dating to over 10,500 cal. B.P. (Zhang et al. 2013); b) modern domestic cattle skull and mandible specimen collected from Henan Province from an animal that died of old age and was not bar-bitted (Institute of Archaeology, Chinese Academy of Social Sciences (IA CASS) collections, Beijing); c) modern musk deer skull and mandible (Muséum national d'Histoire naturelle (MNHN) collections, Paris); d) modern water deer skull and mandible (MNHN); e) Shang dynasty domestic pig skull and mandible (IA CASS). 
questions: 1) What was the history of East Asian aurochs that belong to haplogroup $\mathrm{C}$ ?, and 2) What animal exploitation strategies might mobile hunter-gatherers and agriculturalists have used prior to the arrival of domestic cattle in China? Ancient DNA from Chinese cattle and auroch specimens of the T3 and C haplogroups is currently under investigation (Cai Dawei pers. comm., September 2014; Zhao Xin pers. comm., August 2016). This research will greatly increase our understanding of the relationships between wild and domestic cattle in Eurasia.

Additional zooarchaeological studies of aurochs in China would be necessary in order to clarify whether people managed these animals. People may have experimented with managing aurochs - perhaps by keeping animals as lures to bring other wild animals closer to their camps to facilitate hunting-but such experiments would have been short-lived and did not lead to full domestication. However, in other parts of the world, at sites with similar dates as the Harbin mandible specimen, people were already managing cattle in complex ways. For example, people brought cattle and other animals to the island of Cyprus before 8,000 B.C. There is zooarchaeological evidence for directed breeding of these animals and additional introductions of new domestic lineages from the mainland (Vigne et al. 2011). Therefore, it is possible that people in East Asia were also managing cattle at sites with similar dates during the early Holocene.

Resource management and domestication occur along a fluid and dynamic continuum. Multiple pathways can result in animal domestication (Zeder 2012, 2015). In the future it will be important to consider the nature of auroch exploitation in China and ask why these animals were never domesticated while other animals such as pigs were.

\section{EVIDENCE FOR THE INTRODUCTION OF DOMESTIC CATTLE INTO CHINA DURING THE LATE NEOLITHIC}

Most genetic and zooarchaeological data support the hypothesis that cattle were introduced to China from West Asia between 3600 and 2000 B.C. (Cai et al. 2014; Flad et al. 2007). We discuss both lines of evidence below.

\section{Genetic Evidence}

Two modern mtDNA haplogroups of Bos indicus (I1 and I2) originated in the Indian subcontinent (Chen et al. 2010). Bos taurus has five main mtDNA haplogroups: T (centered in the Near East), T1 (centered in Africa), T2 (centered in the Near East), T3 (centered in the Near East and Europe), and T4 (centered in East Asia) (Achilli et al. 2008; Bradley and Magee 2006; Mannen et al. 2004; Troy et al. 2001). These haplogroups are defined by polymorphisms in a $240 \mathrm{bp}$ region of the mtDNA D-loop (Mannen et al. 2004; Troy et al. 2001). Another Bos taurus haplogroup, T5, is defined based on variants in other areas on the mtDNA genome (Achilli et al. 2008).

Current mtDNA evidence indicates that European domestic cattle are derived from Near Eastern varieties of Bos taurus (Bradley and Magee 2006; Loftus et al. 1994; Loftus et al. 1999; Troy et al. 2001). The origin of African Bos taurus is still debated (Bradley and Magee 2006), but the T1 haplogroup is very closely related to the T2 and T3 haplogroups, suggesting that it also originated in the Near East (Achilli et al. 
2008). Because the T4 haplogroup is only found in East Asian cattle, some have argued that there was another independent domestication event in East Asia (Lai et al. 2006; Mannen et al. 2004); however, more recent research shows that the T4 haplogroup is a derived clade within the T3 haplogroup (Achilli et al. 2009).

Other rare divergent Bos mtDNA haplogroups-P, Q, R, and E-have been identified in modern and ancient cattle populations in Europe, reflecting interbreeding between female wild aurochs and male domestic cattle (Achilli et al. 2009; Achilli et al. 2008; Bailey et al. 1996; Bonfiglio et al. 2010; Edwards et al. 2007; Edwards et al. 2010; Lari et al. 2011; Mona et al. 2010; Schibler et al. 2014; Stock et al. 2009; Zeyland et al. 2013). Analyses of Y-chromosome DNA have also been used to argue for past introgression from male aurochs in Europe (Götherström 2005), but this evidence has since been questioned (Bollongino et al. 2008). Nevertheless, the mtDNA evidence indicates that auroch-domestic cattle hybrids did exist. Moreover, recent whole genome sequencing data from a British auroch specimen provide strong evidence for admixture between European aurochs and domestic cattle of Near Eastern origin (Park et al. 2015). It is still unclear whether such hybrids represent single gene flow events or repeated intentional breeding of aurochs into domestic cattle populations in Europe (Schibler et al. 2014). The possibility for interbreeding between domestic and wild cattle in other regions, including China, has not yet been examined in detail.

In China, studies of mtDNA population structure in living cattle populations reveal that Bos taurus haplogroups are more common in northern China whereas Bos indicus haplogroups are more common in southern China, with evidence for hybridization in-between (Cai et al. 2007; Cai et al. 2014; Lai et al. 2006). Studies of Y-chromosome DNA in modern Chinese cattle show a similar geographic pattern, with Bos taurus haplogroup Y2 predominating in northern China and Bos indicus haplogroup Y3 predominating in southern China (Li, Xie, et al. 2013). This suggests a strong historical north-south divide between taurine cattle and zebu cattle exploitation.

For Bos taurus, both modern and palaeogenetic research support a Near Eastern origin for Chinese cattle. The T2, T3, and T4 haplogroups are the most common haplogroups in modern Chinese populations (Lai et al. 2006). All of these haplogroups are derived from Near East cattle populations (Achilli et al. 2009). Ancient DNA from 46 cattle specimens from northern Chinese archaeological sites dating to c. 2000 B.C. shows that all of the sampled animals also belonged to the T2, T3, and T4 haplogroups of Bos taurus (Cai et al. 2014). The genetic origins of Bos indicus in China are less well understood. Currently, there are no ancient DNA studies of zebu cattle. All of the ancient Chinese cattle specimens studied so far have been identified as Bos taurus (Cai et al. 2014), which suggests that Bos indicus did not enter northern China and the Central Plains until some time after 2000 B.C., but the situation in southern China remains unclear.

Other than the Bos mandible analyzed by Zhang and colleagues (2013), no ancient DNA analyses of cattle specimens dating to before c. 2000 B.C. have been published. Until more studies are published, we cannot say with certainty whether early potential cases of domestic cattle in China all represent domestic populations introduced from outside of China or animals in the process of domestication from native Chinese aurochs. 


\section{Zooarchaeological Evidence}

A comprehensive picture of the zooarchaeogical data for the management of cattle in ancient China requires close analysis of cattle bones from Chinese archaeological sites. We have surveyed published cases with detailed morphological descriptions of bones and complete contextual and zooarchaeological information. This survey relies on identifications that are based on morphological comparisons, size measurements, identification of skeletal pathologies, analysis of herd demographics and age structure, archaeological context, or a combination of these, because only through an assessment of such data can we even begin to consider whether identified cattle bones relate to animal management and domestication (Lu 2010a). Table 1 lists the sites with early evidence for domestic cattle based on our analysis of published faunal materials (for detailed descriptions see Lu 2010a, 2010b, 2010c; Lu et al. 2014), as well as through studies of ancient DNA (Cai et al. 2014) and stable isotopes (Chen, Hu, et al. 2016).

The earliest domestic cattle remains come from the Gansu-Qinghai region of Northwest China. Several possible domestic cattle remains have been found at sites in Gansu Province dating to 3600-2500 B.C. Examples include bones morphologically similar to domestic Bos taurus excavated from Majiayao Culture (c. 3400-2700 B.C.) levels at the sites of Shizhaocun and Xishanping (Flad et al. 2009; Zhou 1999). A cattle scapula used for oracle bone divination has been found from Majiayao Culture layers at the site of Fujiamen (Zhao 1995) (Fig. 3c). This sort of ritual use of animal bones may reflect animal management, although it is important to note that many early oracle bones were not obtained from domesticated taxa (Flad 2008). Bones with size measurements consistent with those for domestic cattle have also been found from Yangshao Culture levels dated to 5600-4900 B.P. at the site of Xishan (Yu et al. 2011). These data suggest that the Gansu-Qinghai region and the Yangshao or Majiayao periods contain evidence for early Chinese exploitation of domestic cattle on a small scale. Even so, the number of cases is limited. With additional data from other regions of China, this picture might change. Bos remains that have size measurements consistent with domestic cattle have also been found at Jiangzhai in Henan Province (Lu 2010b; Qi 1988), but the early date of these remains requires further study.

The earliest definitive evidence for Bos taurus exploitation is found at sites centered along the Yellow River Valley that date to c. 2500-2000 B.c. during the terminal Late Neolithic period. Cattle skeletons buried as sacrificial offerings have been found at Dahezhuang (Fig. 3b) and Qinweijia (Zhongguo Kexue 1974, 1975) in Gansu Province, and at Pingliangtai (Henan and Zhoukou 1983) and Shantaisi (Zhang and Zhang 1997) (Fig. 3a) in Henan Province, again reflecting the use of these animals in important ritual practices. The Shantaisi case is particularly interesting because nine cattle skeletons were found in a sacrificial pit along with a small deer skull, suggesting that wild and domestic animals were sometimes included together in ritual contexts. The Shantaisi bones also have been measured, and their size is consistent with domestic cattle. Numerous sites in Gansu, Qinghai, Shaanxi, Henan, Anhui, and Shandong Provinces contain fragmentary cattle bones in the faunal assemblages, including some that were worked into artifacts such as oracle bones (Table 1; Fig. 3c).

Based on age estimates derived from tooth eruption and wear patterns and horn core morphology, we infer that cattle were domesticated at some sites such as Gu- 

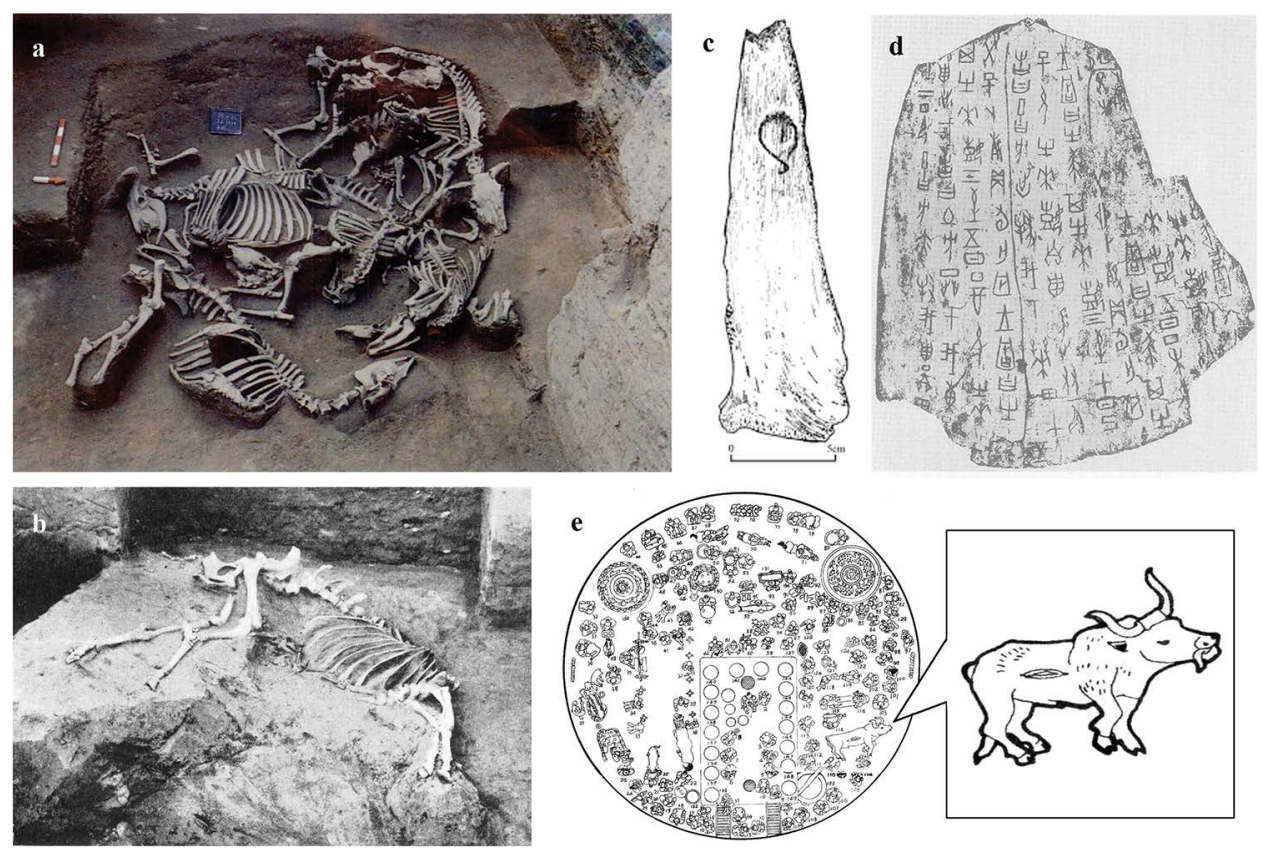

Fig. 3. a) Cattle skeletons found in a sacrificial pit at Shantaisi (Zhang and Zhang 1997); b) female cow skeleton with skull removed and fetal calf remains present inside the stomach, found inside of a building at Dahezhuang (Zhongguo Kexue 1974); c) incised cattle scapula oracle bone from Fujiamen (Zhao 1995); d) Shang dynasty oracle bone with written inscription (Keightley 1999:242, fig. 4.4); e) image of Bos indicus on a bronze drum from Shizhaishan (Zhang 1998).

chengzhai in Henan Province (Lu 2010b). Specifically, the presence of juvenile animals suggests that ancient people were managing the cattle population at Guchengzhai to some degree. Stable isotope analyses of cattle bones from Wadian in Henan Province and Dongying in Shaanxi Province may also reflect cattle management. During the terminal Late Neolithic period, cattle at these sites had elevated $\delta^{13} \mathrm{C}$ signatures, suggesting that people in Central China may have foddered cattle with C4 plants such as domesticated millet (Chen, Fang, et al. 2016; Chen, Hu, et al. 2016). This alone is not proof of domestication since wild cattle could have grazed in millet fields and there are also wild C4 plants in China. Nevertheless, the isotope data provides another supplemental line of evidence pointing to the presence of fully domesticated cattle at these sites.

The proportion of cattle remains in the overall faunal assemblages at terminal Late Neolithic sites is generally low $(\mathrm{Lu} \mathrm{2010b})$, so we believe that cattle were not a significant source of subsistence resources. Instead, they may have been more closely tied to infrequent yet important religious and ritual activities. After about 2000 B.C., cattle herding became widespread across northern China and an increasingly important part of the domestic animal economy. It is safe to accept the domestic status of cattle at these sites due to the large proportion of cattle bones in the faunal assemblages. Domestic cattle played an important role in subsistence, craft production, and ritual practice in northern China after about 2000 B.C. During the late occupation phase of Longshan-period Taosi and Zhoujiazhuang (c. 2000-1900 B.c.) in Shanxi Province, 
for example, cattle make up about $8 \%$ of the mammalian faunal assemblages and cattle bones are one of the main raw materials for bone working and oracle bone production (Brunson et al. 2016). Stable carbon isotope analysis also indicates that cattle at Taosi had elevated $\delta^{13} \mathrm{C}$ signatures, suggesting that they may have been foddered with millet by-products (Chen et al. 2012); however, there is still not sufficient evidence to rule out the possibility that the elevated $\delta^{13} \mathrm{C}$ signatures were caused by feeding on wild C4 plants. Strontium isotope analysis indicates that while some cattle were raised locally, others were brought to the site from surrounding regions (Zhao et al. 2011a). Moreover, all cattle at Taosi and Zhoujiazhuang survived beyond two years of age (Brunson et al. 2016), further suggesting that people at these sites may have paid special attention to raising and caring for adult cattle.

Other sites dating to after 2000 B.C. show similar trends in cattle management. At Xinzhai (c. 2050-1750 B.C.) in Henan Province, cattle make up about 5-10\% of the mammalian faunal assemblage and have elevated $\delta^{13} \mathrm{C}$ signatures that suggest people may have foddered these animals with millet products (Dai et al. 2015). At Zhukaigou (c. 2200-1500 B.C.) in Inner Mongolia, cattle make up between 15 and 40\% of the identified mammal specimens in each occupation phase (Huang 1996). At Erlitou (c. 1900-1500 B.c.) in Henan Province, cattle make up about 10-25\% of identified mammal specimens (Yang 2008), and strontium signatures indicate a mix of local and non-local animals (Zhao et al. 2011b). Zhangdeng (c. 2000-1600 B.c.) in Henan Province has stable carbon and nitrogen isotope signatures for cattle that are consistent with possible millet foddering (Hou et al. 2013). These sites also frequently contain cattle oracle bones and cattle remains in other ritual contexts, indicating that the ritual value of cattle remained high as cattle herding became more common.

It is important to note that there may have been considerable regional variation in herding practices at this time. Atahan and colleagues (2011) found that cattle at Huoshiliang and Gangangwa (c. 2300-1700 B.c.) in Gansu Province had relatively low $\delta^{13} \mathrm{C}$ signatures and highly variable $\delta^{15} \mathrm{~N}$ signatures. They argue that people at these sites may have employed mobile pastoralist strategies in which cattle grazed beyond the agricultural zone. People probably traded and transported animals over great distances to graze in distinct ecological contexts. This would lead to variation in nitrogen signatures due to differences in aridity or salinity. In another example, Qiu and colleagues (2014) conducted palaeobotanical and isotopic analyses of cow dung samples from Xiaohe in Xinjiang (c. 1700-1400 в.C.). They found that cattle were eating primarily C3 plants such as reeds (Phragmites australis) and varying amounts of C4 plants such as grasses (Eragrostis sp.) and sedges (Carex sp.). This shows that elevated carbon isotope signatures may not always be caused by millet foddering. Further research is needed to understand variation in cattle exploitation and dietary composition in different regions.

At sites dating to after c. 2000 B.c., cattle were frequently involved in ritual practices. Examples include the dozens of cattle oracle bones that have been found at sites such as Taosi, Zhoujiazhuang, Zhukaigou, and Erlitou (Brunson et al. 2016; Chen and Li 2013; Huang 1996). At the Xiaohe cemetery in Xinjiang, offerings of cattle skulls, milk, and dung were included in funerary offerings (Qiu et al. 2014). By the Shang dynasty (1600-1046 B.C.), domestic cattle exploitation had become a central part of northern Chinese subsistence and ritual practices (Lu 2015). Millions of cattle were supplied to the largest capital cities such as Anyang in Henan Province; their bones were used to make hairpins and other artifacts in huge bone workshops (Camp- 
bell et al. 2011; Ma 2010). Thousands of cattle were also included in sacrificial offerings at Anyang (Okamura 2005; Yuan and Flad 2005), demonstrating the diverse roles that these animals had at large political centers.

To date, no prehistoric zebu cattle remains have been identified in Chinese archaeological sites. The earliest evidence for Bos indicus in China is an image on a bronze drum dating to the Warring States period (475-221 B.C.) from Shizhaishan in Yunnan Province (Chen 1999; Zhang 1998:41-44, 110-112; Fig. 3e). More zooarchaeological studies of archaeological sites in southern China are needed to determine the timing and routes of introduction for Bos indicus, but it appears that this species was introduced to China from the Indian subcontinent or Southeast Asia several thousand years later than Bos taurus was from the northwest.

\section{THE USE OF CATTLE IN NEOLITHIC AND BRONZE AGE CHINA}

The introduction of Bos taurus into China occurred just prior to the development of the first Chinese states (Chang 1986; Liu and Chen 2003). It also coincided roughly with the appearance of sheep, wheat, and early metal technologies at Chinese archaeological sites c. 3000-2000 B.C. (Barton and An 2014; Cai et al. 2011; Dodson et al. 2013; Flad et al. 2007; Flad et al. 2010; Jaang 2015; Liu et al. 2014). Proto-Silk Road trade routes in Northwest China, especially in the Gansu-Qinghai region, were key pathways through which new Central Asian domesticates and technologies were introduced and adopted according to local environmental and social conditions (Jaang 2015; Liu et al. 2014). Archaeological evidence suggests that when cattle were first introduced into China, they were used at least in four characteristic ways that had an influence on how herding developed during the Late Neolithic and early Bronze Age.

1) Subsistence - Isotopic studies of past human diets indicate that at least some people living at terminal Late Neolithic sites may have been eating beef. For example, Chen and colleagues (2015) found that some human bones at Wadian had elevated $\delta^{15} \mathrm{~N}$ signatures, but low $\delta^{13} \mathrm{C}$ signatures consistent with a primarily $\mathrm{C} 3$ diet. They argue that these individuals may have eaten more sheep and cattle meat than other people at Wadian who had low $\delta^{15} \mathrm{~N}$ and high $\delta^{13} \mathrm{C}$ signatures consistent with low-meat diets of primarily C4-based plants such as millet. However, this alone is not proof that people were eating beef since eating cervids or other wild animals that consume primarily C3 diets would produce a similar pattern. Isotopic evidence for the frequent trade and transport of animals at terminal Late Neolithic and Bronze Age sites further suggests that cattle were supplied to population centers as part of a complex food production process that involved herders who took advantage of new pastoralist landscapes (Atahan et al. 2011; Zhao, Li, et al. 2011; Zhao, Yuan, et al. 2011). Nevertheless, cattle herding remained small-scale during the initial introduction of cattle into China, and cattle bones are only found sporadically or in low frequencies at early sites. Comparisons of the relative proportions of various domestic taxa in Chinese faunal assemblages indicate that pigs remained the most important domestic animals for subsistence throughout the Neolithic and early Bronze Age, with sheep herding predominating at sites in the arid northwest (Luo 2012; Yuan 1999). At sites where cattle bones have been found in sufficient numbers to permit investigation of demographic (kill-off) patterns, there is currently no evidence that herds were managed to produce 
milk for human consumption (Brunson et al. 2016; Lu 2010b). Therefore, the early use of domestic cattle in China was likely not closely associated with a need to raise animals to meet subsistence requirements. Only after c. 2000 B.C., when cattle start to make up significant proportions of Chinese faunal assemblages, did cattle herding become a main source of subsistence products.

2) Cattle as Labor Animals - The introduction of cattle into China was not definitively related to the use of cattle for draft power. The presence of primarily adult and aged cattle at sites such as Taosi could be interpreted as evidence that people kept cattle alive to be used as beasts of burden in old age. However, there is minimal evidence for skeletal pathologies associated with intensive draft activities at Taosi (Brunson et al. 2016). Cart tracks have been found at Erlitou and other Bronze Age sites, but humans may have pulled these carts instead of cattle (Barbieri-Low 2000; Wang 1999). Cattle could also have been used as pack animals rather than for draft. More research is needed before claims can be made about the use of cattle as labor animals. There is currently no evidence that cattle were used consistently for labor at the time of their introduction to northern China (Yuan 2015:263-264).

3) Bone Raw Materials - Cattle provided ancient Chinese artisans with a readily available source of high-quality bone raw materials (Ma 2010). For example, cattle bones were frequently used to make a wide variety of bone tools at sites such as Taosi and Zhoujiazhuang (Brunson et al. 2016). Bovine bones turned into digging tools have also been found at the Qijia Culture period sites of Qinweijia and Dahezhuang in Gansu Province (Zhongguo Kexue 1974:45, 1975:73). At Erlitou, a bone workshop has been discovered in which the predominant raw material was bones from domestic cattle (Chen and Li 2016). By the Erligang and late Shang dynasty periods, cattle were the main species used to make mass-produced bone hairpins and other bone artifacts at huge workshops in Shang capital cities (Campbell et al. 2011; Ma 2010). Raising cattle had become a significant element in the Shang economy, with cattle meat and bones moving around these cities in complex supply and redistribution systems (Campbell et al. 2011). However, it is likely that the availability of cattle bone was a supplementary benefit to raising cattle rather than the initial impetus for adopting cattle herding during the Late Neolithic.

4) Religious Ritual and Sacrifice - The archaeological contexts where Late Neolithic and Bronze Age cattle remains have been found indicate that cattle were valued as

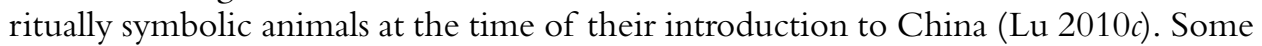
of the earliest evidence for domestic cattle in China comes from sacrificial contexts and oracle bones. This suggests that cattle were associated with rituals tied to elite ancestor worship and methods for legitimizing claims to power and authority. The isotopic evidence that cattle were foddered at sites such as Wadian, Taosi, and Xinzhai indicates that people paid special attention to raising cattle (Brunson et al. 2016; Chen et al. 2012; Chen, Fang, et al. 2016; Dai et al. 2015), possibly because they were considered sacred animals or wealth animals. Between the Late Neolithic and late Shang dynasty, cattle replaced pigs as the most common sacrificial animals (Yuan and Flad 2005). The number of cattle oracle bones also increased through time. By the late Shang dynasty, cattle bones were the most common material used for oracle bone divination, holding a primary role in the rituals tied to royal religious power (Flad 
2008; Keightley 1999) (Fig. 3d). Interestingly, water buffalo also feature prominently in Shang art, such as in the numerous bronzes containing water buffalo imagery or the stone water buffalo figurines from Fuhao's tomb (Zhongguo Shehui 1980:157, 162, 200, 201). The sheer volume of ritual bovine remains indicates that ritual use could have been a major driver in Late Neolithic management systems, at least in the north. Many interesting research questions remain about who controlled these animals, how meat and bone materials were redistributed, and the strategies people used to raise cattle on a large scale in different regions.

\section{SUMMARY AND FUTURE DIRECTIONS}

No definitive evidence for indigenous cattle domestication in China currently exists. Additional research is needed to determine whether people experimented with managing native wild aurochs prior to the introduction of domestic cattle. Genetic and zooarchaeological data both suggest that domestic Bos taurus was introduced to China from West Asia between 3600 and 2000 B.C. Cattle management may have occurred at lower intensities before 2500 B.C., but large-scale cattle exploitation did not take place until after about 2000 B.C. Bos taurus likely entered China through the GansuQinghai region, but the exact timing and routes of introduction are still unknown and it is unclear whether Bos taurus reached China as a single introduction event or in multiple waves. Bos indicus likely entered southern China sometime after 2000 B.C., but the timing and routes of introduction remain a mystery.

Since our current interpretations are based on a small number of sites and samples, more zooarchaeological studies of Late Neolithic faunal assemblages are needed. A key part of this research would be to develop better ways to distinguish between aurochs and domestic cattle through morphometrics, especially since there can be significant size overlap between wild and domestic individuals (Degerbøl and Fredskild 1970; Helmer et al. 2005). Additional techniques may also be useful for identifying wild and domestic bovines, such as the analysis of bone stable isotopes to identify dietary changes indicative of intentional foddering (Chen, $\mathrm{Hu}$, et al. 2016). More ancient DNA studies are also needed to clarify the phylogenetic history of East Asian bovines and identify the origins of early domestic cattle remains.

The initial adoption of cattle herding in China provided people with opportunities to use newly available animal resources in innovative ways. Cattle could be used for subsistence, as draft animals, as sources of raw materials such as bone and hide, and as wealth or ritual animals. People undoubtedly used domestic cattle in multiple ways, but it is likely that ritual demands drove their increasing importance in ancient China. This had an effect on the availability of meat and bone materials that would have provided new economic opportunities in emerging state societies. Future archaeological research is needed to better understand who controlled these animals, the relationships between elites and those who raised the cattle, how cattle were supplied to major urban centers, and whether cattle were raised differently than other domestic animals. Through the development and application of additional genetic and zooarchaeological research, we will better understand the domestication process for Chinese cattle and how the adoption of herding influenced the development of Late Neolithic and Bronze Age societies in China. 


\section{ACKNOWLEDGMENTS}

We would like to thank the Muséum National d'Histoire Naturelle in Paris; the researchers and students at the Institute of Archaeology, Chinese Academy of Social Sciences; the Harvard Fairbank Center for Chinese Studies; the Harvard Department of Anthropology; the UCLA Department of Anthropology; the Cotsen Institute of Archaeology; P. Jeffrey Brantingham; and Rowan Flad. We also thank the anonymous reviewers of previous versions of this article, whose suggestions have greatly improved the manuscript.

\section{REFERENCES CITED}

Achilli, Alessandro, Silvia Bonfiglio, Anna Olivieri, Arianna Malusà, Maria Pala, Baharak Hooshiar Kashani, Ugo A. Perego, Paolo Ajmone-Marsan, luigi liotta, Ornella Semino, Hans-Jürgen Bandelt, Luca Ferretti, and Antonio Torroni

2009 The multifaceted origin of taurine cattle reflected by the mitochondrial genome. PLoS One 4(6) : e5753.

Achilli, Alessandro, Anna Olivieri, Marco Pellecchia, Cristina Uboldi, licia Colli, Nadia Al-Zahery, Matteo Accetturo, Maria Pala, Baharak Hooshiar Kashani, Ugo A. Perego, Vincenza Battaglia, Simona Fornarino, Javad Kalamati, Massoud Houshmand, Riccardo Negrin, Ornella Semino, Martin Richards, Vincent Macaulay, Luca Ferretti, Hans-Jürgen Bandelt, Paolo Ajmone-Marsa, and Antonio Torroni

2008 Mitochondrial genomes of extinct aurochs survive in domestic cattle. Current Biology 18:R157-R158.

AN Jiayuan 安家瑗 AND CHEN HONGHAi 陈洪海

2010 Zongri wenwu yizhi dongwu guge de yanjiu 宗日文化遗址动物骨骼的㸴究 [Research on the animal remains from sites belonging to Zongri culture], in Dongwu kaogu diyiji 动物考古 (第1辑) [Zooarchaeology (volume 1)]: 232-240, ed. Henan Sheng Wenwu Kaogu Yanjiu Suo 河南省文物考古㸴究所编 [Henan Province Institute of Cultural Relics and Archaeology]. Beijing: Wenwu Chuban She.

ANhui Sheng Wenwu KaOgu Yanjiu Suo 安徽省文物考古㸴究所

1992 Anhui sheng suixi xian shishanzi yizhi dongwu guge jianding yu yanjiu 安徽省滩溪县石山子 遗址动物骨骼鉴定与㸴究 [Identification and analysis of animal bones from the Shishanzi site in Suixi County, Anhui Province]. Kaogu 考古 3:253-262, 293-294.

Anthony, David W.

2007 The Horse, the Wheel, and Language: How Bronze-Age Riders from the Eurasian Steppes Shaped the Modern World. Princeton, NJ: Princeton University Press.

Atahan, Pia, John Dodson, Xiaoqiang Li, Xinying Zhou, Songmei Hu, Fiona Bertuch, and NAN SUN

2011 Subsistence and the isotopic signature of herding in the Bronze Age Hexi corridor, NW Gansu, China. Journal of Archaeological Science 38(7): 1747-1753.

Bailey, Jillian F., Martin B. Richards, Vincent A. Macaulay, Isabelle B. Colson, I. Tim James,

Daniel G. Bradley, Robert E. M. Hedges, and Bryan C. Sykes

1996 Ancient DNA suggests a recent expansion of European cattle from a diverse wild progenitor species. Proceedings: Biological Sciences 263(1376): 1467-1473.

BARBIERI-LOW, ANTHONY J.

2000 Wheeled Vehicles in the Chinese Bronze Age (c. 2000-741 B.C.). Sino Platonic Papers No. 99. Philadelphia: Dept. of Asian and Middle Eastern Studies, University of Pennsylvania.

Barton, Loukas, And Cheng-Bang An.

2014 An evaluation of competing hypotheses for the early adoption of wheat in East Asia. World Archaeology 46:775-798.

Bollongino, Ruth, Julia Elsner, Jean-Denis Vigne, and Joachim Burger

2008 Y-SNPs do not indicate hybridisation between European aurochs and domestic cattle (bovine Y-haplotypes). PLoS ONE 3(10): e3418.

Bonfiglio, Silvia Alessandro Achilli, Anna Olivieri, Riccardo Negrini, Licia Colli, Luigi Liotta, Paolo Ajmone-Marsan, Antonio Torroni, and Luca Ferretti

2010 The enigmatic origin of bovine mtDNA haplogroup R: Sporadic interbreeding or an independent event of Bos primigenius domestication in Italy? PLoS One 5(12) : e15760. 
Bradley, Daniel G., and David A. Magee

2006 Genetics and the origins of domestic cattle, in Documenting Domestication: New Genetic and Archaeological Paradigms: 317-328, ed. Melinda A. Zeder, Daniel G. Bradley, Eve Emshwiller, and Bruce D. Smith. Berkeley: University of California Press.

Brunson, Katherine, Nu He, and Xiangming Dai

2016 Sheep, cattle, and specialization: New zooarchaeological perspectives on the Taosi Longshan. International Journal of Osteoarchaeology 26:460-475.

Cai, Dawei, Yang Sun, Zhuowei Tang, Songmei Hu, Wenying Li, Xingbo Zhao, Hai Xiang, and Hui Zhou

2014 The origins of Chinese domestic cattle as revealed by ancient DNA analysis. Journal of Archaeological Science $41: 423-434$.

Cai, Dawei, Zhuowei Tang, Huixin Yu, lu Han, Xiaoyan Ren, Xingbo Zhao, Hong Zhu, and Hui ZHOU

2011 Early history of Chinese domestic sheep indicated by ancient DNA analysis of Bronze Age individuals. Journal of Archaeological Science 38:896-902.

Cai, Xin, Hong Chen, Chuzhao Lei, Shan Wang, Kai Xue, and Bao Zhang

2007 MtDNA diversity and genetic lineages of eighteen cattle breeds from Bos taurus and Bos indicus in China. Genetica 131(2): 175-183.

Campbell, Roderick, Zhipeng Li, Yuling He, and Jing Yuan

2011 Consumption, exchange and production at the Great Settlement Shang: Bone-working at Tiesanlu, Anyang. Antiquity 85(330): 1279-1297.

Chang, KwANG-CHIH

1986 The Archaeology of Ancient China, 4th ed. New Haven, CT: Yale University Press.

Chen GuOliang 陈国梁 AND Li ZHipeng 李志鹏

2013 Erlitou wenhua de zhanbu zhidu chutan-yi Erlitou yizhi jinnian chutu bugu weili 二里头 文化的占卜制度初探一以二里头遗址近年出土卜骨为例 [Erlitou Culture divination systemExamples of oracle bones excavated in recent years], in Sandai Kaogu (5) 三代考古(五): 62-72. Beijing: Kexue Chubanshe.

2016 Erlitou yizhi zhigu yicun de kaocha 二里头遗址制骨遗存的考察 [The observation on the bone workshop remains at Erlitou site]. Kaogu 考古 5:59-70.

Chen, Shanyuan, Bang-Zhong Lin, Mumtaz Baig, Bikash Mitra, Ricardo J. Lopes, António M. Santos, David A. Magee, Marisa Azevedo Pedro Tarroso, Shinji Sasazaki, Stephane Ostrowski, Osman Mahgoub, Tapas K. Chaudhuri, Ya-ping Zhang, Vânia Costa, Luis J. Royo, Félix Goyache, Gordon luikart, Nicole Boivin, Dorian Q. Fuller, Hideyuki Mannen, Daniel G. Bradley, and Albano Beja-Pereira

2010 Zebu cattle are an exclusive legacy of the South Asia Neolithic. Molecular Biology and Evolution 27(1): 1-6.

Chen Wenhua 陈文华

2005 Zhongguo gudai nongye wenming shi 中国古代农业文明史 [History of agricultural civilizations in ancient China]. Nanchang: Jiangxi Kexue Jishu Chubanshe.

Chen, X.-L., Y.-M. Fang, Y.-W., Hu, Y.-F. Hou, P. Lü, J. Yuan, G.-D. Song, B. T. Fuller, and M. P. RICHARDS

2016 Isotopic reconstruction of the Late Longshan Period (ca. 4200-3900 BP) dietary complexity before the onset of state-level societies at the Wadian site in the Ying River Valley, Central Plains, China. International Journal of Osteoarchaeology 26:808-817. doi: 10.1002/oa.2482.

Chen, X.-L., S.-M. Hu, Y.-W. Hu, W.-L. Wang, Y.-Y. Ma, P. Lü, And C.-S. Wang

2016 Raising practices of Neolithic livestock evidenced by stable isotope analysis in the Wei River Valley, north China. International Journal of Osteoarchaeology 26:42-52. doi: 10.1002/oa.2393.

Chen Xianglong 陈相龙, Yuan Jing 袁靖, Hu Yaowu 胡耀武, He Nu 何驽, ANd Wang Changsui 王昌燧

2012 Taosi yizhi jiachu siyang celue, chutan: lai zi tan, dan wending tongweisu de zhengju 陶寺遗址 家畜饲养策略初探：来自碳、氮稳定同位素的证据 [Strategies for raising animals at Taosi: Evidence from nitrogen and carbon isotopes]. Kaogu 考古 9:75-82.

Chen Xiaовo 陈小波

1999 Lingnan diqu niu de kaogu faxin yu yanjiu 岭南地区牛的考古发现与咑究 [Archaeological discoveries and research on cattle in the Lingnan region]. Xueshu Luntan 学术论坛 4:13-18. 
Cucchi, T., A. Hulme-Beaman, J. Yuan, and K. Dobney

2011 Early Neolithic pig domestication at Jiahu, Henan province, China: Clues from molar shape analyses using geometric morphometric approaches. Journal of Archaeological Science 38(1) : 1122.

Dai, L. L., Z. P. Li, C. Q. Zhao, J. Yuan, L. L. Hou, C. S. Wang, B. T. Fuller, and Y. W. Hu

2015 An isotopic perspective on animal husbandry at the Xinzhai site during the initial stage of the legendary Xia dynasty (2070-1600 BC). International Journal of Osteoarchaeology. doi: 10.1002/ oa.2503.

Degerbøl, Magnus, and Bent Fredskild

1970 The Urus (Bos primigenius Bojanus) and Neolithic Domesticated Cattle (Bos taurus domesticus Linné) in Denmark: With a Revision of Bos-remains from the Kitchen Middens. Zoological and Palynological Investigations. København: Munksgaard.

Dodson, John R., Xiaogiang Li, Xinying Zhou, Keliang Zhao, K., Nan Sun, and Pia Atahan 2013 Origin and spread of wheat in China. Quaternary Science Reviews 72:108-111.

Edwards, Ceiridwen J., Ruth Bollongino, Amelie Scheu, Andrew Chamberlain, Anne Tresset, Jean-Denis Vigne, Jillian F. Baird, Greger larson, Simon Y. W. Ho, Tim H. Heupink, Beth Shapiro, Abigail R. Freeman, Mark G. Thomas, Rose-Marie Arbogast, Betty Arndt, László Bartosiewicz, Norbert Benecke, Mihael Budja, louis Chaix, Alice M. Choyke, Eric Coqueugniot, Hans-Jürgen Döhle, Holger Göldner, Sönke Hartz, Daniel Helmer, Barabara Herzig, Hitomi Hongo, Marjan Mashkour, Mehmet Özdogan, Erich Pucher, Georg Roth, Sabine Schade-Lindig, Ulrich Schmölcke, Rick J. Schulting, Elisabeth Stephan, Hans-Peter Uerpmann, István Vörös, Barbara Voytek, Daniel G. Bradley, and Joachim Burger

2007 Mitochondrial DNA analysis shows a Near Eastern Neolithic origin for domestic cattle and no indication of domestication of European aurochs. Proceedings: Biological Sciences 274 : 13771385.

Edwards, Ceiridwen J., David A. Magee, Stephen D. E. Park, Paul A. Mcgettigan, Amanda J. Lohan, Alison Murphy, Emma K. Finlay, Beth Shapiro, Andrew T. Chamberlain, Martin B. Richards, Daniel G. Bradley, Brendan J. Loftus, and David E. MacHugh

2010 A complete mitochondrial genome sequence from a Mesolithic wild aurochs (Bos primigenius). PLoS ONE 5(2) : e9255.

FlaD, RowAN K.

2008 Divination and power: A multiregional view of the development of oracle bone divination in early China. Current Anthropology 49(4) : 403-437.

Flad, Rowan K., Shuicheng Li, Xiaohong Wu, and Zhijun Zhao

2010 Early wheat in China: Results from new studies at Donghuishan in the Hexi corridor. The Holocene 20:955-965.

Flad, Rowan K., Jing Yuan, and Shuicheng Li

2007 Zooarchaeological evidence for animal domestication in Northwest China, in Late Quaternary Climate Change and Human Adaptation in Arid China: 167-204, ed. D. B. Madsen, F. H. Chen, and G. Xing. Amsterdam: Elsevier.

2009 Lun Zhongguo Gan Qing diqu Xinshiqi shidai jiayang dongwu de laiyuan ji tezheng [Discussion of the origin and characteristics of domestic animals in the Neolithic Gansu-Qinghai region of China]. Kaogu 5:80-86, 113.

Frachetti, Michael D.

2008 Pastoralist Landscapes and Social Interaction in Bronze Age Eurasia. Berkeley: University of California Press.

Fu, Ssu-nien, Li Chi, Tung Tso-pin, Liang Ssu-yung, Wu Chin-ting, Kuo Pao-chun, and Liu YU-HSIA.

1934 Cheng-tzu-yai [Chengziyai: The black pottery culture site at Longshanzhen in Lichengxian, Shandong Province]. Nanjing: Institute of History and Philology, Academia Sinica.

Gansu Sheng Bowuguan 甘肃省博物馆

1960 Gansu Wuwei Huangniangniangtai yizhi fajue baogao 甘肃武威皇娘娘台遗址发掘报告 [Excavation report on the Huanniangniangtai site in Wuwei, Gansu Province]. Kaogu Xuebao 考古 学报 $2: 53-71,143-148$.

Götherström, Anders, Cecilia Anderung, Linda Hellborg, Rengert Elburg, Colin Smith, Dan G. Bradley, and Hans Ellegren

2005 Cattle domestication in the Near East was followed by hybridization with aurochs bulls in Europe. Proc Biol Sci 272(1579): 2345-2350. 
Gou, X., Y. Wang, S. Yang, W. Deng, and H. Mao

2010 Genetic diversity and origin of Gayal and cattle in Yunnan revealed by mtDNA control region and SRY gene sequence variation. Journal of Animal Breeding and Genetics 127(2):154-160.

Grigson, Caroline

1982 Sex and age determination of some bones and teeth of domestic cattle: a review of the literature, in Ageing and Sexing Animal Bones from Archaeological Sites: 7-23, ed. B. Wilson, C. Grigson, and S. Payne, BAR British Series 109. Oxford: BAR.

1985 Bos indicus and Bos namadicus and the problem of autochthonous domestication in India, in Recent Advances in Indo-Pacific Prehistory: 425-428, ed. V. N. Misra and Peter Bellwood. New Delhi: Oxford and IBH.

Guo, Songchang, Peter Savolainen, Jianping Su, Qian Zhang, Delin Qi, Jie Zhou, Yang Zhong, Xinquan Zhao, and Jianquan Liu

2006 Origin of mitochondrial DNA diversity of domestic yaks. BMC Evolutionary Biology 6(1): 73.

He Yuling 何毓灵 AND Yue HongBin 岳洪涁

2011 Huanbei Shangcheng shinian zhi huigu 洹北商城十年之回顾 [10-year review on Huanbei Shang dynasty site]. Zhongguo guojia bowuguan guankan 中国国家博物馆馆刊 12:6-19.

Helmer, Daniel, Lionel Gourichon, Hervé Monchot, Joris Peters, and Maria Saña Segui

2005 Identifying early domestic cattle from Pre-Pottery Neolithic Sites on the Middle Euphrates using sexual dimorphism, in The First Steps of Animal Domestication: New Archaeozoological Approaches: 86-95, ed. Jean-Denis Vigne, Joris Peters and Daniel Helmer. Oxford: Oxbow Books.

Henan Sheng Wenwu Kaogu Yanjiu Suo 河南省文物考古研究所

1999 Wuyang Jiahu 舞阳贾湖. Beijing: Kexue Chubanshe.

2001 Zhengzhou Shangcheng: 1953-1985 kaogu fajue baogao 郑州商城：1953-1985考古发掘报告 [1953-1985 excavation report for Zhengzhou Shang dynasty site]: 158, 608, 676-681, 695-699, 829-834, 871. Beijing: Wenwu Chubanshe.

2012 Zhengzhou Xiaoshuangqiao: 1990-2000 Nian kaogu fajue baogao 郑州小双桥：1990-2000年考古 发掘报告 [1990-2000 excavation report for Xiaoshuangqiao site in Zhengzhou city]: 68-117, 528-532, 553-580. Beijing: Kexue Chuban She.

Henan and Zhoukou [Henan Sheng Wenwu Kaogu Yanjiu Suo 河南省交物考古咗究所 AND Zhoukou DiQu Wenwu Ju Wenwu Ke 周口地区文物局文物科]

1983 Henan Huaiyang Pingliangtai Longshan wenhua chengzhi shijue jianbao 河南淮阳平粮台龙山 文化城址试掘简报 [Excavation report for the Longshan Culture site of Pingliangtai in Huaiyang, Henan Province]. Wenwu 文物 3:21-36, 99.

Henan Sheng Wenwuju Wenwu GongZuodui Diyidui 河南省文物局文物工作队第一队

1957 Zhengzhou Shangcheng de fajue 郑州商城遗址的发掘 [Excavation of Zhengzhou Shang dynasty site]. Kaogu Xuebao 考古学报 1:53-73.

Hillson, Simon

2005 Teeth, 2nd ed. Cambridge: Cambridge University Press.

Hongo, Нitomi, Jessica Pearson, Banu Ö́süz, and Gülçın İlgezdi

2009 The process of ungulate domestication at Çayönü, Southeastern Turkey: A multidisciplinary approach focusing on Bos sp. and Cervus elaphus. Anthropozoologica 44(1):63-73.

Hou, Liangliang, Yaowu Hu, Xinping Zhao, Suting Li, Dong Wei, Yanfeng Hou, Baohua Hu, Peng Lu, Tao Li, Guoding Song, and Changsui Wang

2013 Human subsistence strategy at Liuzhuang site, Henan, China during the Proto-Shang Culture ( 2000-1600 BC) by stable isotopic analysis. Journal of Archaeological Science 40(5):23442351.

Hu Songmei 胡松梅, Zhang Pengcheng 张鹏程, AND Yuan Ming 袁明

2008 Yulin Huoshiliang yizhi dongwu yicun yanjiu 榆林火石梁遗址动物遗存咑究 [Research on animal remains from Huoshiliang site in Yulin city]. Renleixue Xuebao 人类学学报 3:232248.

Hu YONGQING 胡永庆

1993 Shilun Zhengzhou Shangcheng chutu de guqi 试论郑州商城遗址出土的骨器 [Discussion of the bone artifact from Zhengzhou Shang dynasty site], in Zhengzhou Shangcheng kaogu xin faxian yu yanjiu (1985-1992) 郑州商城考古新发现与矿究(1985-1992) [Research on the new archaeological discoveries in Zhengzhou Shang dynasty site (1985-1992)]: 78-86, ed. Henan Sheng Wenwu Kaogu Yanjiusuo 河南省文物考古砰究所. Zhengzhou: Zhongzhou Guji Chubanshe. 
HuANG YUNPING 黄蕴平

1996 Neimenggu Zhukaigou yizhi shougu de jianding yu yanjiu 内蒙古朱开沟遗址兽骨的鉴定与 咑究 [Identification and research on faunal remains from Zhukaigou, Inner Mongolia]. Kaogu Xuebao 考古学报 1996(4): 515-536.

JAANG, LI

2015 The landscape of China's participation in the Bronze Age Eurasian network. Journal of World Prehistory 28(3): 179-213.

Kaifeng Diqu Wenwu Guanli Weiyuanhui 开封地区文物管理委员会, Xinzheng Xian Wenwu GuANli WeIYUANHui 新郑县文物管理委员会, AND ZhengZhou Daxue Lishixi KaOgu Zhuanye 郑州 大学历史系考古专业

1979 Peiligang Yizhi 1978 Nian Fajue Jianbao 裴李岗遗址一九七八年发掘简报 [Report on the 1978 Excavations at Peiligang]. Kaogu 考古 3:197-205.

Keightley, David

1999 The Shang: China's first historical dynasty, in The Cambridge History of Ancient China: 232291, ed. M. Loewe and E. Shaughnessy. Cambridge: Cambridge University Press.

KOHL, PHILIP

2007 The Making of Bronze Age Eurasia. Cambridge: Cambridge University Press.

KONG QINGSHENG 孔庆生

1996 Xiaojingshan yizhi zhong de dongwu yihai 小荆山遗址中的动物遗骸 [Animal remains from the site of Xiaojingshan]. Huaxia Kaogu 华夏考古 2:23-28.

Lai, Song-Jia, Yi-Ping Liu, Yan-Xing Liu, Xue-Wei Li, and Yong-Gang Yao

2006 Genetic diversity and origin of Chinese cattle revealed by mtDNA D-loop sequence variation. Molecular Phylogenetics and Evolution 38(1) : 146-154.

lari, Martina, Ermanno Rizzi, Stefano Mona, Giorgio Corti, Giulio Catalano, Kefei Chen, Cristiano Vernesi, Greger larson, Paolo Boscato, Gianluca De Bellis, Alan Cooper, David Caramelli, and Giorgio Bertorelle

2011 The complete mitochondrial genome of an 11,450-year-old Aurochsen (Bos primigenius) from Central Italy. BMC Evolutionary Biology 11(1):32.

Larson, Greger, and Joachim Burger

2013 A population genetics view of animal domestication. Trends in Genetics 29(4) : 197-205.

Larson, Greger, Keith Dobney, Umberto Albarella, Meiying Fang, Elizabeth Matisoo-Smith, Judith Robins, Stewart Lowden, Heather Finlayson, Tina Brand, Eske Willerslev, Peter Rowley-Conwy, Leif Andersson, and Alan CoOper

2005 Worldwide phylogeography of wild boar reveals multiple centers of pig domestication. Science 307(5715) : 1618-1621.

Larson, Greger, Ranran Liu, Xingbo Zhao, Jing Yuan, Dorian Fuller, Loukas Barton, Keith Dobney, Qipeng Fan, Zhiliang Gu, XiaO-Hui Liu, Yunbing Luo, Peng Lu, Leif Andersson, Ning LI, AND OFER BAR-YoseF

2010 Patterns of East Asian pig domestication, migration, and turnover revealed by modern and ancient DNA. Proceedings of the National Academy of Sciences 107(17) : 7686-7691.

Li, Ran, Wen-Mei Xie, Zhen-Hua Chang, Shao-Qiang Wang, Rui-Hua Dang, Xian-Yong Lan, Hong Chen, and Chu-Zhao Lei

2013 Y chromosome diversity and paternal origin of Chinese cattle. Molecular Biology Reports $40(12): 6633$.

\section{ZHIPENG 李志鹏}

2009 Yinxu dongwu yicun yanjiu 殷噓动物遗存咑究 [The study of faunal remains from Yinxu]. Zhongguo Shehui Kexueyuan Yanjiusheng Yuan boshi xuewei lunwen 中国社会科学院 研究生院博士学位论文 [Ph.D. diss. Graduate School of the Chinese Academy of Social Sciences, Beijing].

Li ZHIPENG 李志鹏, YUAN JING 袁靖, AND YANG MENGFEI 杨梦菲

2013 Yanshi Shangcheng yizhi gongcheng wai chutu dongwu yicun 偃师商城遗址宫城外出土动物 遗存 [Research on animal remains outside the palace in Yanshi Shang dynasty site], in Yanshi Shangcheng (diyijuan) 偃师商城 (第一卷) [Yanshi Shang dynasty site (volume 1)]: 435, 676-688, 701-705, 742-749. Beijing: Kexue Chubanshe.

LINDUFF, KATHERYN

2003 A walk on the wild side: Late Shang appropriation of horses in China, in Prehistoric Steppe Adaptation and the Horse: 139-162, ed. M. Levine, C. Renfrew, and K. Boyle. Cambridge: McDonald Institute for Archaeological Research. 
Liu Li 刘莉, YANG Dongya 杨东亚, AND Chen XingCAN 陈星灿

2006 Zhongguo jiayang shuiniu de qiyuan chutan 中国家养水牛的起源初探 [On the origin of the Bubalus bubalis in China]. Kaogu Xuebao 考古学报 2:141-178.

Liu, Li, and Chen Xingcan

2003 State Formation in Early China. London: Duckworth.

Liu, Li, Chen Xingcan, and Jiang Leping

2004 A study of Neolithic water buffalo remains from Zhejiang, China. Bulletin of the Indo-Pacific Prehistory Association 24(2): 113-120.

Liu, Xinyi, Emma Lightfoot, Tamsin C. O’Connell, Hui Wang, Shuicheng Li, Liping Zhou, Yaowu

Hu, Giedre Motuzaite-Matuzeviciute, and Martin K. Jones

2014 From necessity to choice: Dietary revolutions in West China in the second millennium BC. World Archaeology 46(5) : 661-680.

Loftus, R. T., O. Ertugrul, A. H. Harba, M.A.A. El-Barody, D. E. MacHugh, S.D.E. Park, and

D. G. BRADLEY

1999 A microsatellite survey of cattle from a centre of origin: The Near East. Molecular Ecology $8(12): 2015-2022$.

Loftus, R. T., D. E. Machugh, L. O. Ngere, D. S. Balain, A. M. Badi, D. G. Bradley, and E. P. Cunningham

1994 Mitochondrial genetic variation in European, African, and Indian cattle populations. Animal Genetics 25(4) : 265-271.

Lu PENG 吕鹏

2009 Yuzhou Wadian yizhi dongwu yihai de jianding he yanjiu 禹州瓦店遗址动物遗骹的鉴定和 㗑究 [Identification and analysis of faunal remains from Wadian], in Zhonghua wenming tanyuan gongcheng wenji一jishu yu jingji juan 中华文明探源工程文集. 技术与经济卷 [Origin of Chinese civilization project-Volume on technology and economics]: 179-194. Beijing: Kexue Chubanshe.

$2010 a$ Kaogu yizhi chutu jiayang huangniu yihai de panduan biaozhun 考古遗址出土家养黄牛遗骸 的判断标准 [Standards for identifying domestic cattle remains from archaeological sites]. Wen$w u$ Yanjiu, di 17 ji 文物研究, 第17辑: 269-293. Beijing: Kexue Chubanshe.

$2010 b$ Lun Zhongguo jiayang huangniu de qiyuan 论中国家养黄牛的起源 [Discussion of the origins of Chinese domestic cattle]. Dongwu Kaogu, di 1 ji 动物考古, 第一辑: 152-176. Beijing: Wenwu Chubanshe.

2010 c Zhongguo jiayang huangniu de qiyuan jiqi zai zongjiao yishi zhong de yingyong 中国家养 黄牛的起源及其在宗教仪式中的应用 [The origin of Chinese cattle and the use of cattle in religious rituals]. Zhongguo shehui kexueyuan gudai wenming yanjiu zhongxin tongxun 中国社会 科学院古代文明哳究中心通讯 [Newsletter of IA CASS Center for the Study of Ancient Civilizations] 20:57-62.

2010d Huanbei Shangcheng erhao jizhi shuijing chutu dongwu yicun de jianding yu fenxi 洹北商城 二号基址水井出土动物遗存的鉴定与分析 [Identification and analysis of animal remains from well in No. 2 building in Huangbei Shang dynasty site]. Kaogu 考古 $1: 18-22$.

2015 Shang ren liyong huangniu ziyuan de dongwu kaogu xue guancha 商人利用黄牛资源的动物 考古学观察 [Zooarchaeological observations on the uses of cattle resources by Shang people]. Kaogu 考古 $1: 105-111$.

Lu Peng 吕鹏, YuAn Jing 袁靖, AND Li Zhipeng 李志鹏

2014 Zailun Zhongguo jiayang huangniu de qiyuan-Shangque 'Zhongguo dongbei diqu quanshixinzaoqi huangniu de xingtaixue he jiyinxue zhengju’ yiwen 再论中国家养黄牛的起源一 商榷《中国东北地区全新世早期管理黄牛的形态学和基因学证据》一文 [Re-exploration the Origination of Domesticated Cattle in China-Discussion on "Morphological and genetic evidence for early Holocene cattle management in northeastern China"]. Nanfang Wenwu 南方文物 3:48-59.

Lu Peng 吕鹏, Yang Mengfei 杨梦菲, AND YuAn Jing 袁靖

2007 Wangchenggang yizhi dongwu yihai de jianding he yanjiu 王城岗遗址动物遗骹的鉴定和 㗑究 [Identification and analysis of animal remains from the site of Wangchenggang], in Dengfeng Wangchenggang kaogu faxian yu yanjiu (2002-2005) 登封王城岗考古发现与研究 (20022005) [Archaeological discoveries and analysis of Wangchenggang in Dengfeng (2002-2005)]: 574-602. Beijing: Daxiang Chubanshe.

LUO YUNBING 罗运兵

2012 Zhongguo gudai zhu lei xunhua, siyang yu yishixing shiyong 中国古代猪类驯化, 饲养与仪式性 使用 [The domestication, feeding, and ritual use of ancient Chinese pigs]: 185-187. Beijing: Kexue Chubanshe. 
LuO Yunbing 罗运兵, YuAn Jing 袁靖, AND YANG MengfeI 杨梦菲

2015 Jiahu yizhi di qi ci fajue chutu dongwu yicun yanjiu baogao 贾湖遗址第七次发掘出土动物 遗存㸴究报告 [Report on the analysis of animal remains from the seventh excavations at Jiahu], in Wuyang Jiahu (Er) 舞阳贾湖 (二): 333-371, ed. Henan Sheng Wenwu Kaogu Yanjiuyuan and Zhongguo Kexue Jishu Daxue Kejishi Yu Kejikaogu Xi 河南省文物考古 哳究院, 中国科学技术大学科技史与科技考古系. Beijing: Kexue Chubanshe.

LUOYANG BOwUGUAN 洛阳博物馆

1978 Mengjin Xiaopangou yizhi shijue jianbao 孟津小潘沟遗址试掘简报 [Excavation report on the Xiaopangou site in Mengjin]. Kaogu 考古 4:240, 244-255, 292-294.

Ma XiaOlin 马萧林

2010 Guanyu zhongguo guqi yanjiu de gi ge wenti 关于中国骨器硏究的几个问题 [Discussion of a few questions related to Chinese bone artifact research]. Huaxia Kaogu 华夏考古 2:138-142.

Mannen, H., M. Kohno, Y. Nagata, S. Tsuji, D. G. Bradley, J. S. Yeo, D. Nyamsamba, Y. Zagdsuren,

M. Yokohama, K. Nomura, and T. Amano

2004 Independent mitochondrial origin and historical genetic differentiation in North Eastern Asian cattle. Molecular Phylogenetics and Evolution 32(2):539-544.

Meadow, Richard H.

1996 The origins and spread of pastoralism in Northwestern South Asia, in The Origins and Spread of Agriculture and Pastoralism in Eurasia: 390-412, ed. D. R. Harris. Washington, DC: Smithsonian Institution Press.

Meadow, Richard H., and Ajita K. Patel

2003 Prehistoric pastoralism in northwestern South Asia from the Neolithic through the Harappan period, in Indus Ethnobiology: New Perspectives from the Field: 65-93, ed. S. A. Weber and W. R. Belcher. Lanham, MD: Lexington Books.

Mona, Stefano, Giulio Catalano, Martina lari, Greger larson, Paolo Boscato, Antonella Casoli, luca Sineo, Carolina Di Patti, Elena Pecchioli, David Caramelli, and Giorgio BERTORELLE

2010 Population dynamic of the extinct European aurochs: Genetic evidence of a north-south differentiation pattern and no evidence of post-glacial expansion. BMC Evolutionary Biology $10: 83$.

OKamura Hidenori 冈村秀典

2005 Shangdai de dongwu xisheng 商代的动物牺牲 [Shang dynasty animal sacrifice]. Kaoguxue Jikan 考古学集刊 15:216-239. Beijing: Zhongguo Shehui Kexue Chubanshe.

Olsen, SANDra L.

2006 Early horse domestication on the Eurasian steppe, in Documenting Domestication: New Genetic and Archaeological Paradigms: 245-269, ed. Melinda A. Zeder, Daniel G. Bradley, Eve Emshwiller, and Bruce D. Smith. Berkeley: University of California Press.

Park, Stephen D., David A. Magee, Paul A. Mcgettigan, Matthew D. Teasdale, Ceiridwen J. Edwards, Amanda J. Lohan, Alison Murphy, Martin Braud, Mark T. Donoghue, Yuan Liu, Andrew T. Chamberlain, Kévin Rue-Albrecht, Steven Schroeder, Charles Spillane, Shuaishuai Tai, Daniel G. Bradley, Tad S. Sonstegard, Brendan J. Loftus, and David E. MacHugh

2015 Genome sequencing of the extinct Eurasian wild aurochs, Bos primigenius, illuminates the phylogeography and evolution of cattle. Genome Biology 16(1): 1 .

QI GUOQIN 祈国琴

1988 Jiangzhai xinshiqi shidai yizhi dongwu qun de fenxi 姜寨新石器时代遗址动物群的分析 [Analysis of the fauna from the Neolithic site of Jiangzhai], in Jiangzhai: Xinshiqi shidai yizhi fajue baogao 姜寨 : 新石器时代遗址发掘报告 [Jiangzhai: Neolithic site excavation report]: 504-538, ed. Xian Banpo Bowuguan and Shaanxi Sheng Kaogu Yanjiusuo 西安牛坡博物馆, 陕西省 考古㸴究所. Beijing: Wenwu Chubanshe.

Qiu, Qiang, Lizhong Wang, Kun Wang, Yongzhi Yang, Tao Ma, Zefu Wang, Xiao Zhang, Zhengqiang Ni, Fujiang Hou, Ruijun Long, Richard Abbott, Johannes Lenstra, and Jianquan LIU

2015 Yak whole-genome resequencing reveals domestication signatures and prehistoric population expansions. Nature Communications 6. doi:10.1038/ncomms10283.

Qiu, Zhenwei, Yimin Yang, Xue Shang, Wenying Li, Yidilisi Abuduresule, Xingjun Hu, Yan Pan, David K. Ferguson, Yaowu Hu, Changsui Wang, and Hongen Jiang

2014 Paleo-environment and Paleo-diet inferred from Early Bronze Age cow dung at Xiaohe Cemetery, Xinjiang, NW China. Quaternary International 349:167-177. 
Rhode, David, David B. Madsen, P. Jefrrey Brantingham, and Tsultrim Dargye

2007 Yaks, yak dung, and Prehistoric habitation of the Tibetan Plateau, in Late Quaternary Climate Change and Human Adaptation in Arid China: 205-224, ed. D. Madsen, F. H. Chen, and X. Gao. Amsterdam: Elsevier.

Schibler, Jörg, Julia Elsner, And Angela Schlumbaum

2014 Incorporation of aurochs into a cattle herd in Neolithic Europe: Single event or breeding? Scientific Reports $4: 5798$.

Shandong Sheng Wenwu KaOgu Yanjiusuo 山东省文物考古研究所

1985 Chiping Shangzhuang xinshiqi shidai yizhi 茌平俘庄新石器时代遗址 [The Neolithic site of Shangzhuang in Chiping]. Kaogu Xuebao 考古学报 4: 465-505, 547-554.

SherratT, ANDrew

2006 The Trans-Eurasian exchange: The prehistory of Chinese relations with the West, in Contact and Exchange in the Ancient World: 32-53, ed. V. H. Mair. Honolulu: University of Hawai'i Press.

Stock, F., C. J. Edwards, R. Bollongino, E. K. Finlay, J. Burger, and D. G. Bradley

2009 Cytochrome $b$ sequences of ancient cattle and wild ox support phylogenetic complexity in the ancient and modern bovine populations. Animal Genetics 40(5):694-700.

TANG ZHUOwei 汤卓炜, GuO ZhizhONG 郭治中, AND SuO XIUfEN 索秀芬

2004 Baiyinchanghan yizhichutu de dongwu yicun 白音长汗遗址出土的动物遗存 [Animal remains unearthed from Baiyinchanghan], in Baiyinchanghan: Xinshiqi shidai yizhi fajue baogao 白音 长汗：新石器时代遗址发掘报告 [Baiyinchanghan: Excavation report on the Neolithic site]: 546-575, ed. Neimengguo Wenwu Kaogu Yanjiusuo 内蒙古交物考古研究所. Beijing: Kexue Chubanshe.

Troy, Christopher S., David E. Machugh, Jillian F. Bailey, David A. Magee, Ronan T. Loftus, Patrick Cunningham, Andrew T. Chamberlain, Bryan C. Sykes, and Daniel G. Bradley

2001 Genetic evidence for Near-Eastern origins of European cattle. Nature 410(6832) : 1088-1091.

VAN VuURE, Cis

2005 Retracing the Aurochs: History, Morphology and Ecology of an Extinct Wild Ox. Sofia-Moscow: Pensoft.

Verkaar, Edward L. C., Isä̈c J. Nijman, Maurice Beeke, Eline Hanekamp, and Johannes A. LENSTRA

2004 Maternal and paternal lineages in cross-breeding bovine species: Has wisent a hybrid origin? Molecular Biology and Evolution 21(7): 1165-1170.

Vigne, Jean-Denis, Isabelle Carrere, Fracois Briois, and Jean Guilaine

2011 The early process of mammal domestication in the Near East. Current Anthropology $52(\mathrm{~S} 4)$ : S255-S271.

WANG XUERONG 王学荣

1999 Shangdai zaoqi chezhe zu shuanglunche zai Zhongguo de chuxian 商代早期车辙与双轮车在 中国的出现 [Early Shang dynasty cart tracks and the appearance of two-wheeled carts in China]. Sandai Wenming Yanjiu 三代文明硏究 1:239-247.

WANG YitAO 王宜濤

1991 Zijing yizhi dongwu qun jiqi gu huanjing yiyi 紫荆遗址动物群及其古环境意义 [The significance of the fauna and environment at the site of Zijing]. Huanjing Kaogu Yanjiu 环境考古 研究: 96-99. Beijing: Kexue Chubanshe.

Wu Shichi 吴诗池 AND HuAng Guirong 黄桂蓉

1997 Niu nian manhua niu 牛年漫话牛 [A discussion of cattle on the year of the ox]. Nongye Kaogu 农业考古 $1: 286-296$.

XIE, LIYe

2014 Early to Middle Holocene Earth-Working Implements and Neolithic Land-Use Strategies on the Ningshao Plain, China. Ph.D. diss. University of Arizona, Tucson.

Xue XIANGXU 薛祥煦, Li YongXiang 李永项, AND Yu XuEFEng 于雪峰

2005 Shanxi Shenmu Xinhua Yizhi Zhong De Dongwu Yihai 陕西神木新华遗址中的动物遗骸 [Animal remains from Xinhua site, Shenmu County, Shannxi Province], in Shenmu Xinhua 神木新华 [Xinhua site in Shenmu county]: 355-367, ed. Shannxi Sheng Kaogu Yanjiuyuan and Yulin Shi Wenwu Baohu Yanjiusuo 陕西省考古研究所和榆林市交物保护研究所编著. Beijing: Kexue Chubanshe. 
Yang, Dongya, Li Liu, Xingcan Chen, and Camilla F. Speller

2008 Wild or domesticated: DNA analysis of ancient water buffalo remains from north China. Journal of Archaeological Science 35(10): 2778-2785.

YANG JIE 杨杰

2008 Erlitou yizhi chutu dongwu yihai yanjiu 二里头遗址出土动物遗骸研究 [Research on animal remains from Erlitou], in Zhongguo zaoqi qingtong wenhua-Erlitou wenhua zhuanti yanjiu 中国 早期青铜文化一二里头文化专题硏究 [Early Bronze culture in China-Special research on the Erlitou Culture]: 471-539, ed. Zhongguo Shehui Kexueyuan Kaogu Yanjiusuo 中国社会 科学院考古硎究所. Beijing: Kexue Chubanshe.

Yang, Xiaoyan, Zhiwei Wan, Linda Perry, Houyuan Lu, Qiang Wang, Chaohong Zhao, Jun Li, Fei Xie, Jincheng Yu, Tianxing Cui, Tao Wang, Mingqi Li, and Quansheng Ge

2012 Early millet use in northern China. Proceedings of the National Academy of Sciences 109(10): 3726-3730.

Yu Chong 余独, Lu Peng 吕鹏 AND Zhao Congcang 赵丛苍

2011 Gansu sheng Lixian Xishan yizhi chutu dongwu guge jianding yu yanjiu 甘肃省礼县西山遗址 出土动物骨骼鉴定与㸴究 [Identification and research on animal bones from Xishan, Li County, Gansu Province]. Nanfang Wenwu 南方文物 3:73-79.

YUAN JING 袁靖

1999 Lun Zhongguo xinshiqi shidai jumin huoqu roushi ziyuan de fangshi 论中国新石器时代居民 获取肉食资源的方式 [A discussion of meat acquisition during the Chinese Neolithic]. Kaogu Xuebao 考古学报 1:1-22.

2008 The origins and development of animal domestication in China. Chinese Archaeology 8:1-7.

2010 Zhongguo gudai jiayang dongwu de dongwu kaogu xue yanjiu 中国古代家养动物的动物 考古学硏究 [A zooarchaeological analysis of ancient Chinese domesticates]. Disiji Yanjiu 第四纪哳究 $30: 298-306$.

2015 Zhongguo dongwu kaoguxue yanjiu 中国动物考古学硏究 [Zooarchaeological research in China]. Beijing: Wenwu Chubanshe.

YUAN JING, AND Rowan K. FLAD

2002 Pig domestication in ancient China. Antiquity 76(293): 724-732.

2005 New zooarchaeological evidence for changes in Shang dynasty animal sacrifice. Journal of Anthropological Archaeology 24(3) : 252-270.

2006 Research on early horse domestication in China, in Equids in Time and Space: 124-131, ed. M. Mashkour. Proceedings of the 9th Conference of the International Council of Archaeozoology, Durham, NC, August 2002. Oxford: Oxbow Books.

YUAN Jing 袁靖 AND CHEN Liang 陈亮

2001 Mengcheng Yuchisi Yizhi Dongwu Guge Yanjiu Baogao 尉迟寺遗址动物骨骼研究报告 [Report on the research on the animal remains from Yuchisi site], in Mengcheng Yuchisi 蒙城尉迟寺 [Yuchisi site in Mengcheng]: 424-441, ed. Zhongguo shehui yuan kaogu yanjiu suo 中国社会 院考古砰究所. Beijing: Kexue Chubanshe.

YuAN Jing 袁靖, HuANG YunPING 黄蕴平, AND YANG MengfeI 杨梦菲

2007 Gongyuan qian 2500 nian dao gongyuan qian 1500 nian zhongyuan diqu dongwu kaogu xue yanjiu 公元前2500年到公元前1500年中原地区动物考古学㸴究 [Zooarchaeological research on the Central Plains between $2500 \mathrm{BC}$ and $1500 \mathrm{BC}$ ], in Keji kaogu (di er ji) 科技考古 (第二辑) [Science for archaeology (volume 2)]: 12-34, ed. Zhongguo shehui yuan kaogu yanjiu suo 中国社会院考古硏究所. Beijing: Kexue Chubanshe.

YUAN JING 袁靖 AND TANG JiGEN 唐际根

2000 Henan Anyang shi Huanbei Huayuanzhuang yizhi chutu dongwu guge yanjiu baogao 河南 安阳市洹北花园庄遗址出土动物骨骼研究报告 [Research on the animinal remains from Huanbei Huayuanzhuan site, Anyang City, Henan Province]. Kaogu 考古 11:75-81.

Yue, Xiang-Peng, Ran Li, Wen-Mei Xie, Ping Xu, Ti-Cheng Chang, Li Liu, Feng Cheng, RunFeng Zhang, Xian-Yong Lan, Hong Chen, and Chu-Zhao Lei

2013 Phylogeography and domestication of Chinese swamp buffalo. PloS One 8(2): e56552.

Zeder, Melinda A.

2012 The domestication of animals. Journal of Anthropological Research 68(2): 161.

2015 Core questions in domestication research. Proceedings of the National Academy of Sciences 112(11):3191-3198.

Zeyland, J., Ł. Wolko, J. Bocianowski, M. Szalata, R. Słomski, A. M. Dzieduszycki, M. Ryba, H. Przystalowska, and D. Lipiński

2013 Complete mitochondrial genome of wild aurochs (Bos primigenius) reconstructed from ancient DNA. Polish Journal of Veterinary Sciences 16(2) : 265-273. 
Zhang Changshou 张长寿 AND Zhang GuANGZHI 张光直

1997 Henan Shangqiu diqu Yin Shang wenming diaocha fajue chubu baogao 河南商丘地区殷商 文明调查发掘初步报告 [Preliminary report on survey and excavations for the Shang civilization project in Shangqiu, Henan Province]. Kaogu 考古 4:24-31, 97.

Zhang, Hucai, Johanna L. A. Paijmans, Fengqin Chang, Xiaghong Wu, Guangjie Chen, Chuzhao Lei, Xiujuan Yang, Zhenyi Wei, Daniel G. Bradley, ludovic Orlando, Terry O'Connor, and Michael Hofreiter

2013 Morphological and genetic evidence for early Holocene cattle management in northeastern China. Nature Communications $4: 2755$.

ZHANG XING 张行

2001 Gansu gu shengwu huashi yu jiushuqi shidai kaogu 甘肃古生物化石与旧石器时代考古 [Biological fossils and Paleolithic archaeology of Gansu Province]: 56-86. Gansu: Gansu Wenwu Chubanshe.

ZHANG ZENGQI 张增棋

1998 Jinning Shizhaishan 晋宁石寨山. Kunming: Yunnan Meishu Chubanshe.

Zhao Chunyan 赵春燕, Li Zhipeng 李志鹏, YuAn Jing 袁靖, Zhao Haitao 赵海涛, Chen Guoliang 陈国梁, AND Xu HoNG 许宏

2011 Erlitou Yizhi chutu dongqu laiyuan chutan-Genju ya youzhi de si tongweisu bizhi fenxi 二里头遗址出土动物来源初探一根据牙釉质的锶同位素比值分析 [Preliminary analysis of the origins of animals at Erlitou-Strontium isotope analysis of archaeological tooth enamel]. Kaogu 考古 $7: 68-75$.

ZhaO ChUnyan 赵春燕, YUAN Jing 袁靖, AND He Nu 何努

2011 Shanxi Sheng Xiangfen Xian Taosi yizhi chutu dongwu ya youzhi de si tongweisu bizhi fenxi 山西省襄汾县陶寺遗址出土动物牙釉质的锶同位素比值分析 [Strontium isotope analysis of archaeological fauna from the Taosi site]. Disiji Yanjiu 第四纪咑究 31(1) : 22-28.

ZHAO XIN 赵信

1995 Gansu Wushan Fujiamen Shiqiang wenhua yizhi fajue jianbao 甘肃武山傅家门史前文化遗址 发掘简报 [Excavation report for the prehistoric culture site of Fujiamen in Wushan, Gansu Province]. Kaogu 考古 4:289-296, 304, 385.

ZHi TIANFU 到田夫

1980 Shandong Cao Xian Shenzhongji yizhi shijue jianbao 山东曹县莘冢集遗址试掘简报 [Excavation report for the Shenzhong site in Cao County, Shandong Province]. Kaogu 考古 5:385$390,481$.

Zhongguo Kexue [Zhongguo Kexue Yuan Gu Jizhui Dongwu Yanjiu Suo Gaodeng Jizhui DONGWU ZU 中国科学院古奉椎动物研究所高等脊椎动物组]

1959 Dongbei disiji buru dongwu huashi zhi 东北第四纪哺乳动物化石志 [Quaternary mammalian fossils from the northeast]. Gu Jichui Dongwu Yanjiu Suo Jiazhong Zhuankan 古脊椎动物研究所 家中专刊 [Special issue from the Institute of Vertebrate Paleontology] 3. Beijing: Kexue Chubanshe.

1974 Gansu Yongqing Dahezhuang yizhi fajue baogao 甘肃永靖大何庄遗址发掘报告 [Excavation report for Dahezhuang in Yongqing, Gansu Province]. Kaogu Xuebao 考古学报 2:29-62, 144-161.

Zhongguo Kexue [Zhongguo Kexue Yuan Gu Jizhui Dongwu Yanjiu Yu Gu Renlei Yanjiu Suo 中国科学院古脊椎动物与古人类研究所]

1979 Zhongguo Jizhui Dongwu Huashi Shouce 中国脊椎动物化石手册 [Manual on Chinese vertebrate fossils]: 615-620. Beijing: Kexue Chubanshe.

Zhongguo Kexue [Zhongguo Kexue Yuan Kaogu Yanjiu Suo Gansu Gongzuo Dui 中国科学院 考古研究所甘肃工作队]

1975 Gansu Yongqing Qinweijia Qijia wenhua mudi 甘肃永靖秦魏家齐家文化墓地 [The Qijia Culture cemetery at Qinweijia in Yongqing, Gansu Province]. Kaogu Xuebao 考古学报 2:5796.

Zhongguo Shehui [Zhongguo Shehui Kexue Yuan Kaogu Yanjiu Suo Bianzhu 中国社会科学院 考古砰究所编著]

1980 Yinxu Fuhao mu 殷噓妇好墓第 [Yinxu Fuhao’s tomb]. Beijing: Kexue Chubanshe.

ZhONGGUO Shehui [ZhONgGuO SheHui KeXueYuan KaOgu Yanjiusuo 中国社会科学院考古研究所]

2002 Henan Yanshi Shangcheng Shangdai zaoqi wangshi jisi yizhi 河南偃师商城商代早期王室祭祀 遗址 [Sacrificial relic of a royal family from Yanshang early Shang dynasty site, Henan Province]. Kaogu 考古 $7: 6-8$. 
Zhongguo Shehui [Zhongguo Shehui Kexueyuan Kaogu Yanjiusuo Anyang Dui 中国社会科学院 考古咑究所安阳队]

1990 Anyang Dahancun Nangang yizhi 安阳大寒村南岗遗址 [Dahancun Nangang site in Anyang]. Kaogu Xuebao 考古学报 1:43-68, 136-141.

Zhongguo Shehui [Zhongguo Shehui Kexueyuan Kaogu Yanjiusuo Henan Dier Gongzuodui 中国社会科学院考古咑究所河南第二工作队]

1988 Henan Yanshi Shiyanggou Shangcheng diwuhao gongdian jizhi fajue jianbao 河南偃师户乡沟 商城第五号宫殿基址发掘简报 [Excavation report for No. 5 palace in Yanshi Shang dynasty site, Shixianggou Town, Yanshi City, Henan Province]. Kaogu 考古 2:128-140, 193-195.

Zhongguo Shehui [Zhongguo Shehui Kexueyuan Kaogu Yanjiusuo Henan Yidui 中国社会科学院 考古㸴究所河南一队]

19841979 nian Peiligang yizhi fajue baogao 1979年裴李岗遗址发掘报告 [1979 excavation report for Peiligang]. Kaogu Xuebao 考古学报 $1: 23-52$.

Zhongguo Shehui and Shandong [Zhongguo Shehui Kexueyuan Kaogu Yanjiusuo Shandong Yanjiudui and Shandong Sheng Weifang DiQu Yishuguan 中国社会科学院考古所山东工作队, 山东省潍坊地区艺术馆]

1985 Weixian Lujiakou Xinshiqi shidai yizhi 潍县鲁家口新石器时代遗址 [Neolithic site of Lujiakou in Weixian]. Kaoguxuebao 考古学报 3:313-351.

ZHOU BENXIONG 周本雄

1981 Hebei Wuan Cishan yizhi de dongwu guhai 河北武安磁山遗址的动物骨骹 [Animal remains from the Cishan site in Wuan, Hebei Province]. Kaogu Xuebao 考古学报 3:339-349.

1983 Henan Tangyin Baiying Henan Longshan wenhua yizhi de dongwu yihai 河南汤阴白营河南 龙山文化遗址的动物遗骸 (Animal remains from the Henan Longshan Culture site of Baiying in Tangyin, Henan Province]. Kaoguxue Jikan (disanji) 考古学集刊(第三集)：48-50. Beijing: Zhongguo Shehui Kexueyuan Chubanshe.

1999 Shizhaocun yu Xishanping yizhi de dongwu yicun 师赵村与西山坪遗址的动物遗存 [Faunal remains from Shizhaocun and Xishanping], in Shizhaocun $y u$ Xishanping 师赵村与西山坪 [Shizhaocun and Xishanping]: 335-339, ed. Zhongguo Shehui Kexueyuan Kaogu Yanjiusuo [Institute of Archaeology, Chinese Academy of Social Sciences]. Beijing: Zhongguo da bake quanshu chubanshe. 